\title{
Exercise Training-Induced Changes in MicroRNAs: Beneficial Regulatory Effects in Hypertension, Type 2 Diabetes, and Obesity
}

\author{
Alex Cleber Improta Caria ${ }^{1,2}$, Carolina Kymie Vasques Nonaka ${ }^{2,3}$, Ciro Silveira Pereira ${ }^{2}$, \\ Milena Botelho Pereira Soares $2,3,4$, Simone Garcia Macambira 1,2,4,5,* and \\ Bruno Solano de Freitas Souza $2,3,4, *$ (D)
}

1 Multicentric Program of Post-Graduate in Biochemistry and Molecular Biology, Federal University of Bahia, Bahia 40231-300, Brazil; alexcaria.personal@hotmail.com

2 Center for Biotechnology and Cell Therapy, São Rafael Hospital, Bahia 41253-190, Brazil; carolina.nonaka@hsr.com.br (C.K.V.N.); ciro_bm@yahoo.com.br (C.S.P.); milena@bahia.fiocruz.br (M.B.P.S.)

3 Gonçalo Moniz Institute, Oswaldo Cruz Foundation (FIOCRUZ), Bahia 40296-710, Brazil

4 National Institute of Science and Technology for Regenerative Medicine, Rio de Janeiro 21941-590, Brazil

5 Department of Biochemistry and Biophysics, Health Sciences Institute, Federal University of Bahia, Bahia 40231-300, Brazil

* Correspondence: simonegm@ufba.br (S.G.M.); bruno.souza@bahia.fiocruz.br (B.S.d.F.S.); Tel.: +55-71-3283-8914 (S.G.M.); +55-71-3176-2260 (B.S.d.F.S.)

Received: 11 October 2018; Accepted: 19 October 2018; Published: 15 November 2018

\begin{abstract}
MicroRNAs are small non-coding RNAs that regulate gene expression post-transcriptionally. They are involved in the regulation of physiological processes, such as adaptation to physical exercise, and also in disease settings, such as systemic arterial hypertension (SAH), type 2 diabetes mellitus (T2D), and obesity. In SAH, microRNAs play a significant role in the regulation of key signaling pathways that lead to the hyperactivation of the renin-angiotensin-aldosterone system, endothelial dysfunction, inflammation, proliferation, and phenotypic change in smooth muscle cells, and the hyperactivation of the sympathetic nervous system. MicroRNAs are also involved in the regulation of insulin signaling and blood glucose levels in T2D, and participate in lipid metabolism, adipogenesis, and adipocyte differentiation in obesity, with specific microRNA signatures involved in the pathogenesis of each disease. Many studies report the benefits promoted by exercise training in cardiovascular diseases by reducing blood pressure, glucose levels, and improving insulin signaling and lipid metabolism. The molecular mechanisms involved, however, remain poorly understood, especially regarding the participation of microRNAs in these processes. This review aimed to highlight microRNAs already known to be associated with SAH, T2D, and obesity, as well as their possible regulation by exercise training.
\end{abstract}

Keywords: microRNAs; systemic arterial hypertension; type 2 diabetes mellitus; obesity; exercise training; microRNA

\section{Introduction}

\subsection{MicroRNAs}

MicroRNAs (miRNAs) are small non-coding single-stranded RNAs, with approximately 22 nucleotides, that act in mechanisms of post-transcriptional regulation of gene expression [1]. miRNAs are abundant in prokaryotic and eukaryotic organisms, being widely distributed among species and frequently conserved [2]. The database miRBase 22 has cataloged 38,589 hairpin precursor miRNAs, 
which are associated with the expression of 48,885 mature miRNA products in 271 species [3,4]. The mechanisms of action of miRNAs rely on the recognition and binding to the $3^{\prime}$-untranslated region ( $3^{\prime}$-UTR) of the target mRNAs [5]. This can lead to mRNA degradation, deadenylation, or the inhibition of translation [6,7].

It is estimated that miRNAs are involved in the regulation of up to $60 \%$ of the protein-coding genes in the human genome [8-10]. Furthermore, the individual genetic background can affect the ability of miRNAs to bind to target mRNA and regulate gene expression. Approximately $11 \%$ of the currently known single nucleotide polymorphisms (SNPs) are located in the 3'-UTR of several genes, which may interfere with the miRNA-mRNA interaction due to the destruction of the binding site or through the creation of new binding sites [11,12]. A significant number of SNPs are also located within the sequences of pri-, pre-, and mature miRNAs [11]. There is growing evidence of the involvement of such gene polymorphisms in the development of a great number of diseases such as hypertension, diabetes, obesity, and cardiovascular diseases [13,14].

Besides the role of individual variability, one of the many challenges involved in the study of miRNAs' regulatory network is the ability of each single miRNA to regulate multiple targets, which adds complexity to the analysis and interpretation of the results [15]. It can be challenging to establish the biological significance of altered microRNA profiles in different settings, tissues, and compartments $[16,17]$. Nevertheless, it is clear that miRNAs promote a fine-tune regulation of a variety of biological processes that include cell metabolism, maturation, survival, proliferation, differentiation, and apoptosis. Therefore, miRNAs can have their expression altered under physiological conditions, and may be involved in the pathogenesis of diseases [18,19].

\subsection{MiRNAs as Mediators and Biomarkers of Cardiovascular Diseases}

MiRNAs are promising tools for the diagnosis, prognosis, or therapeutic guidance, applied as biomarkers of cardiovascular diseases. The discovery of altered miRNA expression profiles, defining a molecular signature for specific diseases, may increase pathophysiological knowledge and help in identifying novel therapeutic targets. Circulating miRNAs are remarkably stable, being transported as (i) ribonucleoprotein complexes, principally Argonaute, (ii) associated with high- and low-density lipoproteins or (iii) inside extracellular vesicles [20-22]. Studies on extracellular vesicles (EVs) date back to the 1960s and, since then, the role of EVs to cell-to-cell communications have been well established. EV's allow for the stable transport of microRNAs, protecting them from enzymatic and physical degradation, allowing for their assessments and applications as biomarkers and/or therapeutic targets [23-25]. Both intracellular and circulating miRNAs can be found dysregulated in cardiovascular diseases, which facilitates their application as novel biomarkers $[20,26]$.

Cardiovascular diseases are estimated to affect 422.7 million people and are the largest contributors to worldwide mortality [27]. The death rate associated with systemic arterial hypertension (SAH) increased by $34.7 \%$ in the latest years [28]. Cardiovascular events are the main cause of death in patients with diabetes mellitus [29]. Type 2 Diabetes mellitus (T2D) is a highly prevalent metabolic disease, with more than 400 million currently affected people in the world. It is estimated that more than 640 million will be affected by T2D by 2040 [30]. Diabetes can progressively lead to cardiac dysfunction, representing an independent risk factor for cardiac diseases [31]. In 2013, the American Medical Association recognized obesity as a disease, which is now considered to be a worldwide epidemic [32]. This is a progressive and multifactorial disease characterized by an increase of white adipose tissue due to both hypertrophy and hyperplasia of adipocytes [33]. Moreover, obesity is highly associated with T2D and cardiovascular diseases [34-36]. The involvement of dysregulated miRNAs in $\mathrm{SAH}, \mathrm{T} 2 \mathrm{D}$, and obesity is reviewed below.

\section{MiRNAs and Systemic Arterial Hypertension (SAH)}

SAH is clinically defined as a persistent non-physiological elevation of systemic arterial pressure. It is considered to be a multifactorial clinical condition, which develops as the result of genetic 
predisposition and environmental factors [37]. Hypertension is one of the main etiologies of cardiovascular diseases, strokes, and kidney failure [38], leading to premature death and disability. It is associated with $45 \%$ of deaths due to heart disease and $51 \%$ of deaths due to strokes [39]. SAH is an independent risk factor for ischemic cardiomyopathy and is present in $64 \%$ of patients with acute myocardial infarction. There are several risk factors for SAH, which can be classified as non-modifiable risk factors-age, ethnicity, gender, and genetics—or modifiable risk factors, such as sedentary lifestyle, psychological stress, smoking, obesity, alcoholism, caffeine consumption, diabetes mellitus type 2, and others [40].

Different pathophysiological processes involved in SAH are now known to be regulated by miRNAs, including endothelial dysfunction, dysregulation of vascular smooth muscle cells (VSMCs), the increase of sympathetic system activity, and alterations in renin-angiotensin-aldosterone system (RAAS) [41,42]. The results of several experimental studies, both in vitro and in vivo, as well as clinical studies, revealed that the expression of different miRNAs can be altered in the context of SAH (Figure 1).

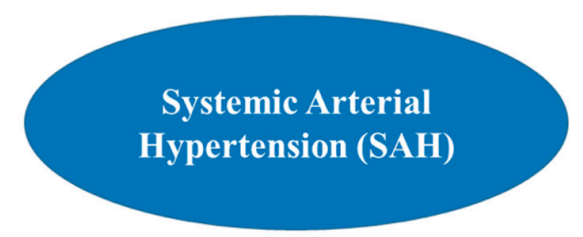

\begin{tabular}{|l|}
\hline ENDOTHELIAL \\
DYSFUNCTION \\
\hline${ }^{67}$ let-7g $\downarrow$ \\
${ }^{55} \mathrm{miR}-15 \mathrm{~b} \downarrow$ \\
${ }^{55} \mathrm{miR}-16 \downarrow$ \\
${ }^{60} \mathrm{miR}-17-3 \mathrm{p} \downarrow$ \\
${ }^{65} \mathrm{miR}-19 \mathrm{a} \downarrow$ \\
${ }^{66} \mathrm{miR}-19 \mathrm{~b} \downarrow$ \\
${ }^{68} \mathrm{miR}-21 \uparrow$ \\
${ }^{60} \mathrm{miR}-31 \downarrow$ \\
${ }^{53} \mathrm{miR}-126 \downarrow$ \\
${ }^{87} \mathrm{miR}-155 \downarrow$ \\
${ }^{70} \mathrm{miR}-223 \uparrow$ \\
${ }^{57} \mathrm{miR}-505 \uparrow$ \\
\hline
\end{tabular}

\begin{tabular}{|c|c|}
\hline $\begin{array}{c}\text { ARTERIAL } \\
\text { REMODELING }\end{array}$ & $\begin{array}{c}\text { RENIN- } \\
\text { ANGIOTENSIN- } \\
\text { ALDOSTERONE }\end{array}$ \\
\hline $\begin{array}{l}{ }^{75} \mathrm{miR}-14 \\
{ }^{75} \mathrm{miR}-21 \uparrow \\
{ }^{80} \mathrm{miR}-26 \mathrm{a} \downarrow \\
{ }^{81} \mathrm{miR}-34 \mathrm{~b} \downarrow \\
{ }^{71} \mathrm{miR}-130 \mathrm{a} \uparrow \\
{ }^{77} \mathrm{miR}-133 \downarrow \\
{ }^{76} \mathrm{miR}-143 \downarrow \\
{ }^{76} \mathrm{miR}-145 \\
{ }^{74} \mathrm{miR}-153 \uparrow \\
{ }^{72} \mathrm{miR}-221 \uparrow \\
{ }^{78} \mathrm{miR}-365 \uparrow\end{array}$ & $\begin{array}{l}{ }^{85} \mathrm{miR}-27 \mathrm{a} / \mathrm{b} \uparrow \\
{ }^{88} \mathrm{miR}-29 \mathrm{~b} \uparrow \\
{ }^{88} \mathrm{miR}-29-3 \mathrm{p} \uparrow \\
{ }^{88} \mathrm{miR}-132 \uparrow \\
{ }^{82} \mathrm{miR}-132 / 122 \uparrow \\
{ }^{10} \mathrm{miR}-143 / 145 \\
{ }^{83} \mathrm{miR}-146 \mathrm{a} / \mathrm{b} \\
\\
{ }^{87} \mathrm{miR}-155 \downarrow \\
{ }^{90} \mathrm{miR}-181 \mathrm{a} \downarrow \\
{ }^{88} \mathrm{miR}-212 \uparrow \\
{ }^{86} \mathrm{miR}-483-3 \mathrm{p} \downarrow \\
{ }^{88} \mathrm{miR}-487 \mathrm{~b} \uparrow\end{array}$ \\
\hline
\end{tabular}

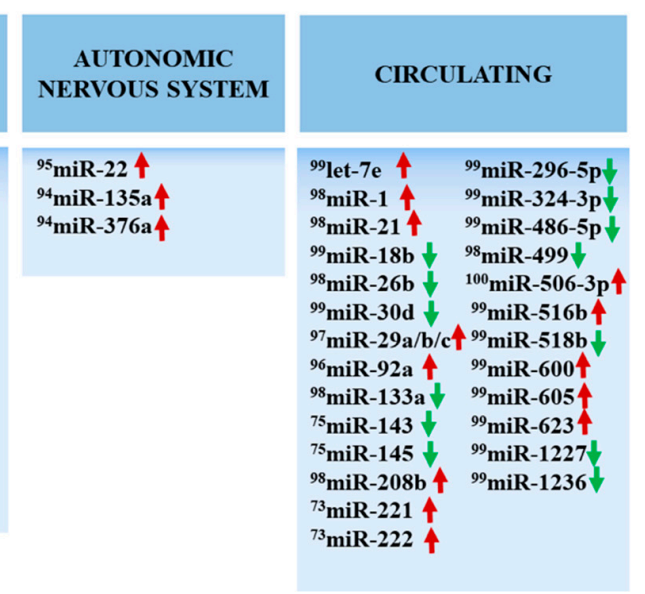

Figure 1. The dysregulated miRNA profile in Hypertension. The diagram shows the miRNA expression pattern associated with different pathophysiological mechanisms involved in hypertension, including endothelial dysfunction, arterial remodeling, renin-angiotensin-aldosterone system (RAAS), and autonomic nervous system. Circulating miRNAs evaluated in serum, plasma, whole-blood, or mononuclear cells, in clinical studies, are also listed. $\uparrow=$ upregulated, $\downarrow=$ downregulated.

\subsection{MiRNAs and Endothelial Dysfunction in $S A H$}

Normal endothelial functions include the maintenance of vascular integrity and homeostasis, leukocyte adhesion, the regulation of vascular tone, and tissue repair [43,44]. In SAH, however, endothelial dysfunction occurs in response to a high shear stress in the vessel wall, which is associated with modifications of intracellular pathways and the impaired expression of constitutive endothelial nitric oxide synthase (eNOS) [45]. Several miRNAs are involved in the link between endothelial dysfunction and hypertension by controlling endothelial cell gene expression and function in the physiological and pathological states [46].

It is known that the vascular endothelial growth factor (VEGF) signaling is altered in SAH. Under physiological conditions, VEGF is not only involved in angiogenesis but also in blood pressure regulation. In fact, the use of anti-VEGF therapies can be associated with the development of SAH as an adverse effect [47]. In the last decade, a considerable amount of data regarding the regulation of VEGF signaling by miRNAs has emerged [48,49]. 
MiR-126 is highly expressed in the cardiac endothelium, being involved in the regulation of the VEGF signaling pathway. MiR-126 participates in processes of angiogenesis and the maintenance of vascular integrity, by targeting the PI3K regulatory subunit p85 $\beta$ (PIK3R2), which leads to modulation of the PI3K/Akt signaling pathway in endothelial progenitor cells [50]. In addition to PIK3R2, miR-126 also inhibits SPRED-1 (Sprouty-related, EVH1 domain-containing protein 1), another negative regulator of angiogenesis that acts by inhibiting VEGF signaling pathway. Indeed, when normally translated, PI3KR2 and SPRED-1 inhibit RAF1 and PI3K, which are required for the activation of the VEGF pathway. Therefore, inhibition of PI3KR2 and SPRED-1 allows for the activation of the VEGF pathway and, consequently, favors angiogenesis under physiological conditions [51]. Transgenic mice lacking the miR-126 expression present developmental abnormalities that include vascular leakage, hemorrhaging, and partial embryonic lethality [52]. These findings were attributed to the compromised signaling of proangiogenic growth factors in the absence of miR-126.

The MiR-126 expression was reported to be reduced in peripheral blood mononuclear cells (PBMCs) of hypertensive patients and, along with miR-9, showed a negative correlation with the 24-h mean pulse pressure [53]. Decreased levels of miR-126 in endothelial cells favor inflammation, as demonstrated by the increased Tumor necrosis factor alpha (TNF- $\alpha$ )-stimulated expression of vascular cell adhesion molecules (VCAM-1) in endothelial cells transfected with a miR-126 inhibitor [54]. MiR-15b and miR-16 are also involved in the regulation of angiogenesis and vascular function. Both miRNAs have VEGF mRNA as a direct target and were found to be downregulated in hypoxic conditions [55].

In addition to VEGF, fibroblast growth factors (FGFs) are also strong promoters of angiogenesis [56]. FGF18, a proangiogenic factor, is repressed by miR-505 in endothelial cells and was found up-regulated in the plasma of hypertensive patients [57]. Interestingly, miR-505 also presented a non-significant trend to be increased in pre-hypertensives subjects, when compared to controls, also suggesting a potential role as a biomarker of pre-hypertension.

MiR-17-3p and miR-31, shown to be altered in SAH, promote vascular inflammation through the modulation of the expression of VCAM-1, ICAM-1, and E-SEL [58-60]. Moreover, vascular inflammation is associated with increased oxidative stress, which can lead to eNOS uncoupling, decreased nitric oxide (NO) production (contributing to endothelial dysfunction) and decreased vasodilation ability $[61,62]$. MiR-155 regulates endothelium-dependent vasodilation by reducing the eNOS mRNA [63] and also plays a role as an anti-angiogenic miRNA in the regulation of adaptive neovascularization [64]. Additionally, miR-19a presents anti-proliferative properties in endothelial cells by inhibiting cyclin D1 mRNA [65], while miR-19b reduces the apoptosis of endothelial cells exposed to TNF- $\alpha$ in vitro [66]. Let-7g, miR-21, and miR-223 may also play a role in apoptosis of endothelial cells [67-69]. Interestingly, the level of miR-223 was shown to be increased during the establishment and progression of hypertension-induced heart failure in an experimental model in rats [70].

\subsection{MiRNAs and Arterial Remodeling in $S A H$}

The proliferation of VSMCs is one of the hallmarks of the vascular response in SAH, a process leading to the structural remodeling of the arteries, with lumen reduction [71]. Vessel wall damage induces changes in gene expression profile and phenotype of VSMCs, increasing their proliferation, migration, and collagen synthesis, while the expression of contractile proteins is decreased [9]. Several miRNAs have already been reported to participate in the regulation of the VSMCs' phenotype, including miR-221, -222, -153, -143, -145, -133, -21,-1, -130a, -365, and -26a, which are discussed below.

MiR-221 regulates the phenotype of VSMCs by reducing their contractile profile in response to the platelet-derived growth factor (PDGF) [72]. Interestingly, circulating levels of miR-221 and miR-222 were found to be increased in hypertensive patients when compared to the controls and were even higher in hypertensive patients that presented left ventricular hypertrophy, which suggests a possible role of these two microRNAs in the complications associated with SAH [73]. MiR-153 was 
found increased in VSMCs in spontaneously hypertensive rats and may compromise the contractile phenotype by targeting the Potassium Voltage-Gated Channel Subfamily Q Member 4. This channel controls arterial contraction and is compromised in hypertension due to miR-153 overexpression [74].

In hypertensive patients, reduced circulating levels of miR-143, miR-145, miR-133 and the increased expression of miR-21 and miR-1 were found [75]. The MiR-143/145 cluster is highly expressed in VSMCs under physiological conditions and plays a role in the differentiation of stem/progenitor cells into VSMCs. The underexpression of the miR-143/145 cluster in SAH may influence the contractile phenotype of VSMCs [10,75,76]. MiR-133 is a negative regulator of VSMCs' proliferation [77], while miR-21 upregulation was shown to be involved in the processes of proliferation and survival of VSMCs [19].

Other miRNAs were shown to be involved in the regulation of the proliferative response of VSMCs. MiR-130a inhibits the growth arrest-specific homeobox, contributing to the VSMCs' proliferation [71]. In contrast, miR-365 inhibits the proliferation of VSMCs by down-regulating cyclin D1 expression. Various stimuli, including angiotensin II signaling, lead to the downregulation of miR-365, which, in turn, results in an increased VSMC proliferation [78,79]. MiR-26a promotes aberrant VSMC proliferation, being involved in the regulation of SMAD- 1 and SMAD- 4 , two members of the TGF- $\beta$ (Transforming Growth Factor $\beta$ ) signaling pathway [80]. In spontaneously hypertensive rats, the downregulation of miR-34b was observed, which favored the proliferation of VSMCs by increasing the levels of cyclin-dependent kinase 6 (CDK6) [81].

\subsection{MiRNAs and Renin-Angiotensin-Aldosterone System (RAAS) in SAH}

MiRNAs participate in RAAS-mediated cardiovascular inflammation. Some miRNAs have been linked to the RAAS signaling, such as miR-155, miR-146a/b, miR-132/122 cluster, and miR-483-3p [82-84]. MiR-145, miR-27a/b, and miR-483-3p inhibit ACE expression, an enzyme that plays a crucial role in the regulation of blood pressure [85,86]. Interestingly, the miR-143/145 cluster is underexpressed in SAH, correlating with a higher expression of ACE [10].

Different miRNAs that target angiotensin II mRNA, including miR-483-3p and miR-155, are downregulated in SAH, leading to an increased angiotensin II expression [86,87]. The persistently increased production of angiotensin II facilitates the development of cardiac hypertrophy in SAH through actions of the following miRs: miR-487b, miR-29b, miR-29-3p, miR-212, and miR-132 [88].

Finally, it was demonstrated that miR-181a inhibits renin mRNA in a genetically hypertensive mouse strain [89] Additionally, MiR-181a has been shown to bind to the 3'-UTR of renin mRNA [90] and was found downregulated in hypertensive mice, correlating with an increased expression of renin and angiotensin II [89]. In hypertensive human subjects, however, a different result was observed, since miR-181a expression was increased in the serum and positively correlated with systolic and diastolic blood pressure, independently of renin levels [91].

\subsection{MiRNAs and Autonomic Nervous System in SAH}

Neurogenic abnormalities in specific sites of central blood pressure control also lead to hypertension. Central neuronal mechanisms of blood pressure involve particular anatomic structures in the brainstem, such as the nucleus of the solitary tract and rostral ventrolateral medulla which play different roles in pressure control. Elevated sympathetic nervous system activity contributes to the overactivation of the RAAS, vascular injuries, remodeling, and endothelial dysfunction. Vascular damage due to inflammation [92] and angiotensin signaling alteration [93] is the main mechanism that leads to neurogenic hypertension. In spontaneously hypertensive rats, this is associated with the dysregulation of miR-135a and miR-376a [94].

Chromogranin A (Chga) is a molecule involved in the central and peripheral blood pressure controls and also in the pathogenesis of $\mathrm{SAH}$, since neuronal Chga-granules store catecholamines in the brainstem and release these neurotransmitters to regulate sympathetic outflow to the periphery. In spontaneously hypertensive rats, the adrenal glands and plasma are elevated but its central expression 
is decreased, thus, miR-22 was associated with the dysregulation of Chga in brainstem cardiovascular control nuclei, contributing to the pathogenesis of SAH in spontaneously hypertensive rats [95].

These results indicate the contribution of miRNAs to the regulation of blood pressure in physiological and pathophysiological conditions by different peripheral and neuronal cells, which reveals the potential of miRNAs as important biomarkers for the diagnosis of $\mathrm{SAH}$, and, future, as therapeutic targets.

\subsection{Circulating miRNAs in $S A H$}

In addition to the miRNAs described above, a number of studies have focused on the search for circulating miRNAs that could serve as SAH biomarkers in the future. As mentioned before, circulating miRNAs have the potential to become novel biomarkers, since they are involved in different biological processes, may be detected during early disease pathogenesis, are easily extracted from peripheral blood, and remarkably stable.

Different studies point to different profiles of miRNA expression in the circulation. Plasma levels of miR-92a were found to be increased in hypertensive subjects and to correlate with $24 \mathrm{~h}$ mean systolic and diastolic pressure [96]. In another study, plasma levels of mir-29a, b, and c were increased in subjects with hypertension, with positive correlations with office systolic and diastolic blood pressure, office pulse pressure, $24 \mathrm{~h}$ mean systolic and diastolic blood pressure, and $24 \mathrm{~h}$ mean pulse pressure [97]. The increased expression of miR-1, miR-21, miR-208b, and miR-499, accompanied by decreased levels of miR-133a and miR-26b, were found in PBMCs of hypertensive subjects, being associated with left ventricular hypertrophy [98]. Plasma levels of miR-516b, miR-600, miR-605, miR-623, and let-7e were increased in hypertensive subjects, while miR-18b, miR-30d, miR-296-5p, miR-324-3p, miR-486-5p, miR-518b, miR-1236, and miR-1227 were decreased when compared to the controls [99]. A recent study revealed that miR-506-3p is elevated in the peripheral blood of hypertensive subjects, also showing a correlation with the stage of hypertension [100]. The lack of consensus in these studies may be influenced by factors such as sample diversity, the degree of disease severity, comorbidities, therapeutic approach, and disease staging.

\subsection{Single Nucleotide Polymorphisms and miRNAs in $S A H$}

SNPs in the 3'-UTR of diverse genes are involved in the establishment of a hypertensive phenotype. Genetic predisposition to essential hypertension was associated with the ss52051869 SNP, which is located in the 3'-UTR of SLC7A1, the L-arginine transporter gene, and leads to endothelial dysfunction and disturbances in the L-arginine and nitric oxide metabolism [101]. Later, it was demonstrated that this SNP creates miRNA-122 binding sites, decreasing SLC7A1 expression in hypertensive patients. The rs5068 (A/G) allele in the 3'-UTR of the NPPA gene, that encodes atrial natriuretic peptide (ANP), is also involved in hypertension. It was shown that miR-425, a specific microRNA expressed in the human atria and ventricles, binds to the sequence spanning rs5068 in an allele-specific manner at the A allele, conferring a regulatory role for microRNA-425 in ANP expression [102]. In 2014, Maharjan and colleagues demonstrated that an SNP located in the Cyp11B2 gene, which encodes for human aldosterone synthase, creates a binding site for miR-766. The binding of miR-766 to the 735G-allele of Cyp11B2 leads to a reduction in the expression of human aldosterone synthase and decreased blood pressure levels [103]. An SNP at the 3'-UTR of the ATF1 (activating transcription factor 1) gene altered the posttranscriptional regulation of this gene by miRNAs, leading to essential hypertension with high ATF-1 expression [104]. The ATF1 rs11169571 allele is involved in the pathogenic mechanism of essential hypertension by altering the hsa-miR-1283 binding site. Another SNP associated with essential hypertension is located at the 3'-UTR of the NET gene, which encodes the norepinephrine transporter (NET), responsible for the removal of Norepinephrine from the neuroeffector junction. The presence of the T allele of rs7194256 (C/T) is strongly associated to cardiovascular abnormalities such as an elevated larger left ventricular mass index, systolic and diastolic blood pressures, augmentation, and uncontrolled heart rate. The rs7194256 SNP in the 3'-UTR of the NET gene 
at $\mathrm{T}$ allele has a binding site for the microRNA miR-19a-3p. This miRNA is significantly reduced in patients that have clinical symptoms of NET impairment due to high levels of Norepinephrine circulating, which lowered the miR-19a-3p levels.

\section{MiRNAs and Type 2 Diabetes Mellitus}

T2D continues to grow in terms of worldwide prevalence, being associated with a high morbidity and mortality [30]. T2D develops as the result of combined genetic predisposition and environmental factors, which include a hypercaloric diet, obesity, and a sedentary lifestyle [105]. Insulin resistance in target tissues is the primary pathogenic mechanism of T2D that leads to hyperglycemia. A constant glucose elevated level is a permanent insult to the expansion of $\beta$-cell mass to increase insulin secretion. However, this compensatory mechanism to maintain glucose homeostasis fails in T2D patients, leading to chronic hyperglycemia and hyperinsulinemia [106]. The molecular mechanisms underlying insulin resistance, impairment of insulin signaling, and exhaustion of pancreatic $\beta$-cells are not completely elucidated.

The evaluation of circulating miRNAs, including those transported by extracellular vesicles (EVs), could help to reach an early diagnosis of T2D, risk stratification, monitorization of disease progression, and therapeutic guidance. The EVs participate in intercellular communication interfering in many biological processes such as cell proliferation and differentiation, immunomodulation, homeostasis, and neurological signaling. EVs are also involved in the pathogenesis of diseases, including T2D [107-109]. The profile of microRNAs transported inside EVs can be associated with aging, changes in tissue microRNA signatures, receptor signaling dysregulation, and gene expression alterations $[110,111]$. The regulation of microRNA expression is associated with different comorbidities and complications of T2D, including impaired angiogenesis and micro and macrovascular injury [108]. Several miRNAs known to be altered in T2D (Figure 2) are described below.

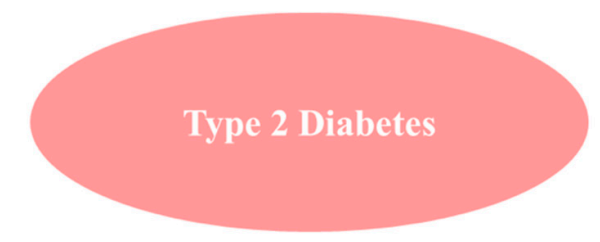

\begin{tabular}{|c|c|}
\hline $\begin{array}{c}\text { INSULIN } \\
\text { SYNTHESIS AND } \\
\text { HYPERGLYCAEMIA }\end{array}$ & $\begin{array}{c}\text { INTRACELLULAR } \\
\text { SIGNALING } \\
\text { INSULIN RESISTANCE }\end{array}$ \\
\hline 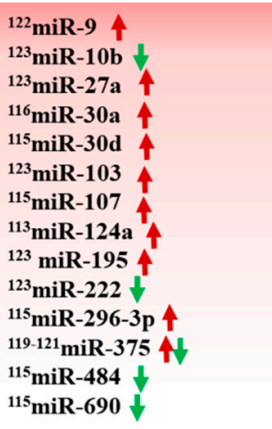 & 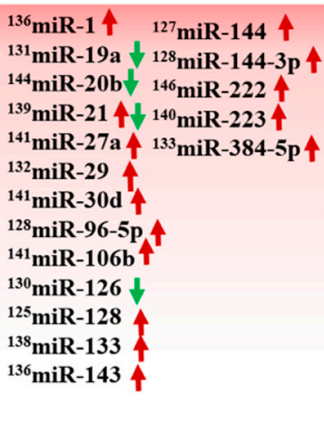 \\
\hline
\end{tabular}

\begin{tabular}{|c|c|c|c|}
\hline $\begin{array}{c}\text { LIPID } \\
\text { METABOLISM }\end{array}$ & \multicolumn{3}{|c|}{ CIRCULATING } \\
\hline $\begin{array}{l}{ }^{150} \mathrm{miR}-14 \downarrow \\
152-153 \mathrm{miR}-33 \uparrow \\
{ }^{149} \mathrm{miR}-122 \uparrow \\
{ }^{157} \mathrm{miR}-130 \\
{ }^{156} \mathrm{miR}-181 \mathrm{a} \\
{ }^{149} \mathrm{miR}-370 \uparrow \\
{ }^{151} \mathrm{miR}-378 / 378 * \uparrow\end{array}$ & $\begin{array}{l}{ }^{160} \mathrm{let}-7 \mathrm{i} \\
{ }^{120} \mathrm{miR}-9 \\
144 \mathrm{miR} 15 \mathrm{a} \\
{ }^{146} \mathrm{miR}-19 \\
144 \mathrm{miR}-20 \mathrm{~b} \\
{ }^{144} \mathrm{miR}-21 \\
160 \mathrm{miR}-23 \mathrm{a} \\
{ }^{144} \mathrm{miR}-24 \\
{ }^{120} \mathrm{miR}-29 \mathrm{a} \uparrow \\
120 \mathrm{miR}-30 \mathrm{~d} / \mathrm{e} \uparrow \\
{ }^{120} \mathrm{miR}-34 \mathrm{a} \\
160 \mathrm{miR}-96 \uparrow \\
121 \mathrm{miR}-101 \uparrow \\
120 \mathrm{miR}-124 \mathrm{a} \\
146 \mathrm{miR}-125 \mathrm{~b} \\
1142-146 \mathrm{miR}-126 \\
125-126 \mathrm{miR}-128\end{array}$ & $\begin{array}{l}{ }^{157} \mathrm{miR}-130 \mathrm{a} \downarrow \\
{ }^{146} \mathrm{miR}-130 \mathrm{~b} \downarrow \\
{ }^{125-126} \mathrm{miR}-130 \mathrm{~b}-3 \mathrm{p} \uparrow \\
{ }^{159} \mathrm{miR}-138 \downarrow \\
{ }^{146} \mathrm{miR}-140-5 \mathrm{p} \uparrow \\
{ }^{146} \mathrm{miR}-142-3 \mathrm{p} / 5 \mathrm{p} \uparrow \\
{ }^{128} \mathrm{miR}-144-3 \mathrm{p} \uparrow \\
{ }^{120} \mathrm{miR}-146 a \uparrow \\
{ }^{160} \mathrm{miR}-186 \downarrow \\
{ }^{144} \mathrm{miR}-191 \\
{ }^{160} \mathrm{miR}-192 \downarrow \\
{ }^{144} \mathrm{miR}-197 \\
{ }^{146} \mathrm{miR}-222 \\
{ }^{144} \mathrm{miR}-223 \\
{ }^{144} \mathrm{miR}-320 \\
{ }^{158} \mathrm{miR}-320 \mathrm{~b} \downarrow\end{array}$ & 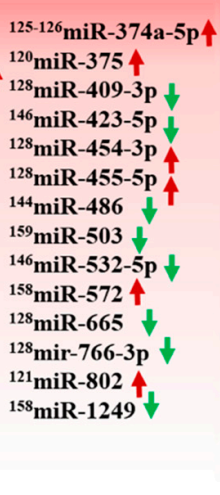 \\
\hline
\end{tabular}

Figure 2. The dysregulated miRNA profile in Type 2 Diabetes. The diagram shows the miRNA expression pattern associated with different pathophysiological mechanisms involved in type 2 Diabetes, including insulin synthesis, intracellular signaling/insulin resistance, lipid metabolism, and hyperglycemia. Circulating miRNAs evaluated in serum, plasma, whole-blood, or mononuclear cells, in clinical studies, are also listed. $\uparrow=$ upregulated, $\downarrow=$ downregulated, $\uparrow \downarrow=$ studies differ and report either increased or decreased expression of the miRNA. 


\subsection{MiRNAs, Insulin Synthesis, and Secretion}

High blood glucose levels lead to increased insulin production by increasing transcription, mRNA stability and translation in pancreatic $\beta$ cells [112]. Different miRNAs, including miR-124a [113,114], miR-107 [115], miR-30a [116], and miR-30d [115] are involved in the regulation of insulin transcription and translation in response to high glucose. The downregulation of miR-484, miR-690, and miR-296 was observed in diabetic mouse pancreatic islets, being associated with the inhibition of insulin transcription [115]. Interestingly, the upregulation of miR-296-3p was associated with pancreatic cell resistance to apoptosis in a pro-inflammatory environment [117]. Besides regulating gene expression by translational repression, miRNAs can also be tissue-specific or exhibit a developmental-stage-specific expression, which could modulate different biological processes. One of these processes is insulin secretion, being regulated by different miRNAs, including miR-375 [112], and miR-9 [118].

The molecular mechanisms involved in the chronic adaptation of pancreatic $\beta$-cells to hyperglycemia are not fully elucidated. Different experimental models were used to investigate the role of different miRNAs in the control of intracellular pathways critical to insulin signaling, such as PI3K-PDK1-AKT (phosphatidylinositol-4,5-bisphosphate 3-kinase/Phosphoinositide-dependent protein kinase-1/AKT/Protein kinase B (PKB), serine/threonine-specific protein kinase). An in vitro study demonstrated that miR-375 reduces PDK1 levels, impairing the glucose-mediated increase in insulin expression. Moreover, miR-375 was found downregulated in pancreatic islets from Goto-Kakizaki (GK) type 2 diabetic rats [119]. In contrast, miR-375 was found upregulated in the serum of newly diagnosed T2D patients [120]. Indeed, another study reported increased serum levels of miR-375 in T2D patients, along with miR-101 and miR-802 [121].

Insulin secretion can also be affected by the overexpression of miR-9, which targets the transcription factor Onecut-2, leading to the increased expression of Granuphilin/Slp4, a negative regulator of insulin secretion [122]. Moreover, it has been demonstrated that miR-222, miR-27a, miR-195, miR-103, and miR-10b expression patterns varied with hyperglycemia in insulin-target tissues of non-obese diabetic rats, suggesting a role in the disease pathogenesis [123].

\subsection{MiRNAs and Insulin Resistance}

A high-fat and sugar diet is associated with hyperglycemia, hyperlipidemia, and insulin resistance. In this context, the pattern of phosphorylation in serine residues of insulin receptor substrate-1 (IRS-1) and insulin receptor substrate-2 (IRS-2) can be altered. In healthy individuals, IRS-1 and IRS-2 tyrosine residues are usually phosphorylated, leading to the activation of insulin signaling cascades [124]. When the phosphorylation of serine residues occurs, however, reduced stimulation of these receptors by phosphoinositide 3-kinase (PI3K) occurs, leading to the reduced activation of the $\mathrm{PI} 3 \mathrm{~K} / \mathrm{AKT} / \mathrm{mTOR}$ (mammalian target of rapamycin) pathway and impaired translocation of GLUT (glucose transporter)-4-containing vesicles to the cell membrane, decreasing glucose uptake [31].

The expression of IRS-1, a key protein in the insulin cascade, is negatively regulated by different miRNAs, including miR-128, which was found to be increased in the serum of pre-diabetic and T2D subjects, along with miR-130b-3p and miR-374a-5p [125,126]. IRS-1 levels also showed a negative correlation with increased miR-144 expression in the whole blood of T2D subjects, exhibiting a correlation with progressively increased glycemic status [127]. In another study, miR-96-5p, which also targets IRS-1, was found overexpressed in the serum of T2D subjects, along with miR-144-3p, miR-454-3p, and miR-455-5p, while miR-409-3p, miR-665, and miR-766-3p were reduced [128]. IRS-1 is also negatively regulated by miR-126, which was found to be overexpressed by hepatocytes in an in vitro model of insulin resistance [129]. MiR-126 was also found to be over-expressed in the adipose tissue of hyperinsulinemic obese mice, targeting IRS-1, and, consequently, impairing glucose uptake [130].

The translocation of GLUT to the plasma membrane of target cells must occur in order to promote glucose uptake. Specific miRNAs interfere in the insulin signaling pathway by targeting the PI3K/AKT axis, which is involved in the translocation of GLUT4 to the cell surface. This is the 
case for miR-19a [131], miR-29 [132], and miR-384-5p [133], with altered expression in T2D. MiR-29 inhibits the insulin-stimulated glucose uptake, and promotes insulin resistance, resulting in the development of T2D [134,135]. The mechanisms involved in this regulation consist in the reduction of AKT phosphorylation, mediated by miR-29, miR-1, and miR-33a/b, or in the direct regulation of AKT mRNA mediated by miR-143 [136]. Furthermore, GLUT4 transcription is regulated by the transcription factor Kruppel-like 15 (KLF15), which is targeted by the miR-133 family [137,138]. MiR-223 and miR-21 also participate in the regulation of GLUT4 translation, as demonstrated by in vitro studies $[139,140]$. In a model of T2D induced by high-fat diet/streptozotocin in rats, miR-106b, miR-27a, and miR-30d were upregulated, leading to the inhibition of GLUT4, MAPK 14, and PI3K [141].

Clinical studies have consistently shown that circulating levels of miR-126 are downregulated in T2D patients [142-146]. The MiR-126 expression was decreased before the manifestation of T2D, correlating with disease onset [143] and high blood glucose levels [144]. Plasma levels of miR-126, as well as miR-20b, miR-21, miR-24, miR-15a, miR-191, miR-197, miR-223, miR-320, and miR-486, were found to be reduced, while miR-28-3p was increased in T2D subjects [144]. In another study, miR-126 was also found to be reduced in the plasma of T2D subjects, along with miR-423-5p, miR-125b, miR-192, miR-130b, miR-19, and miR-532-5p, while miR-140-5p, miR-142-3p, and miR-222 were upregulated [146]. Interestingly, progressively lower circulating levels of miR-126-3p and miR-21-5p were found in healthy controls compared to T2D subjects and T2D with complications [145]. It is possible that the downregulation of miR-126 counteracts angiogenesis, since miR-126 was also found with a reduced expression in endothelial progenitor cells obtained from T2D patients, correlating with a decreased proliferation, migration, and increased induction of apoptosis, through the disinhibition of SPRED1, which in its turn inhibits the Ras/ERK/VEGF and PI3K/Akt/eNOS signal pathways [147]. These data suggest that miR-126 may be involved in the pathogenesis of micro- and macrovascular complications of T2D.

\subsection{MiRNAs and Lipid Metabolism}

It is well established that insulin resistance is associated with changes in the expression of miRNAs that regulate the lipid metabolism. Hepatic expression of miR-122 is involved in cholesterol and fatty acid metabolism [148]. The increased expression of miR-370 activates the expression of miR-122 and affects the lipid metabolism, increasing hepatic triglycerides accumulation [149]. MiR-14 also regulates the fat metabolism, as shown by the increased levels of triacylglycerol and diacylglycerol found in miR-14 null animals [150]. MiR-378/378* (MiR378-5p and 378-3p) play important roles in regulating lipid metabolism and their overexpression increases triacylglycerol during adipogenesis [151], while miR-33 targets genes involved in cholesterol transport (ABCA1) and controls HDL (High Density Lipoprotein) levels in vivo [152,153].

It has been reported that Sirtuin 1 (SIRT1) regulates the glucose and lipid metabolism [154]. MiR-181a regulates SIRT1, increasing the insulin sensitivity in hepatocytes [155]. The increased cardiac expression of p53 and p21 and the decreased expression of miR-181a was reported in diabetic subjects, suggesting a possible role for this microRNA in the development of diabetic cardiomyopathy [156]. Levels of miR-130a were found to be reduced in the peripheral blood of T2D subjects and in the omental adipose tissue of T2D subjects, while the target mRNA levels—PPAR $\gamma$ — were elevated [157].

\subsection{Circulating miRNAs in $T 2 D$}

The evaluation of expression levels of different miRNAs in plasma samples revealed that the pattern of expression of miR-1249, miR-320b, and miR-572 can distinguish T2D patients, prediabetes, and controls [158]. Moreover, lean diabetic patients can be distinguished from obese diabetic patients by the combined evaluation of miR-503 and miR-138 levels [159]. A prediction analysis of genes regulated by these miRNAs points to different biological functions, which include development, signal transduction, cell survival, cell differentiation, cell proliferation, apoptosis, cell metabolism, and ion transport regulation. In another study, decreased plasma levels of miR-15a, miR-20b, miR-21, 
miR-24, miR-126, miR-191, miR-197, miR-223, miR-320, and miR-486 were found in T2D subjects [144]. Although these studies identified many different miRNA that could help reach an early diagnosis and acting as novel therapeutic targets, their function in the pathogenesis of T2D is far from being clarified.

Interestingly, miR-126 was associated with an increased risk for development of diabetes in the future, but the correlation with the other miRNAs detected in T2D is not fully elucidated [144]. Kong and colleagues, 2011, investigated the role of seven miRNAs that had been previously described as key regulatory elements in insulin synthesis, secretion, and signaling, as well as free fatty acid action on pancreatic $\beta$-cells. They found increased levels of miR-9, miR-29a, miR-30d, miR-34a, miR-124a, miR-146a, and miR-375 in serum samples of newly diagnosed T2D patients, which differed from pre-diabetes individuals with impaired glucose tolerance and those without it [120]. So, the profile of miRNA expression varies with the stage of the disease. Yang and colleagues revealed low serum levels of miR-23a, let-7i, miR-486, miR-96, miR-186, miR-191, miR-192, and miR-146a in T2D subjects [160].

\subsection{Single Nucleotide Polymorphisms and miRNAs in T2D}

Different gene variants have been reported to increase the susceptibility or to participate in the pathogenesis of T2D [161,162]. SNPs in different genes involved in T2D pathogenesis were reported, including transcription factor 7-like 2-TCF7L2 [163], Angiotensin-converting enzyme [164], Adiponectin [165], IGF2 receptor [166], and Sirtuins-SIRT [167]. Insulin-like growth factor (IGF) and its receptor (IGF type 2 receptor: IGF2R) are involved in a variety of physiological events including glucose homeostasis [168]. Genetic variants of this receptor were associated with diabetes [169-171]. The evaluation of the IGF2R genotypes distributions in diabetes patients revealed that the CC allele had a higher frequency among these patients than the others investigated alleles (CT or TT), thus affecting the circulating IGF2R levels distribution and T2D development [166]. However, the role of genetic variants of the IGF2R system in type 2 diabetes mellitus is still unclear. Lv and colleagues (2008) demonstrated that the ACAA-insertion/deletion polymorphism in IGF2R 3'-UTR is located within some specific miRNAs binding sites that result in the individual variability of IGF2R expression [172]. It was demonstrated in a prediction analysis and in vitro experiments that among the miRNA identified the hsa-miR-657 was involved in the inhibitory interaction with 3'-UTR of the IGF2R gene, resulting in the modulation of IGF2R expression in an allele-specific manner.

The Lipoprotein lipase (LPL) is a key enzyme in lipid metabolism and abnormalities in its function are associated with dyslipidemia, insulin resistance, and T2DM. A study conducted in Iranian DM carriers analyzed the correlation between SNP rs13702 (C/T) in the 3'-UTR binding site to miRNA-410 of LPL gene and T2DM susceptibility. This SNP leads to an impairment in the LPL system due to dysfunction in gene expression negative regulation by miRNA-mRNA interaction. This abnormality has as one of its features the higher circulating levels of LPL that leads to ectopic fat deposition in peripheral tissues and contributes to insulin resistance, hyperglycemia, and progressively to T2DM [173].

Polymorphisms in the sequence of pri-miRNA have been reported for miR-124a, which regulates pancreatic islet development and insulin secretion by targeting Foxa2 and Rab27a [113,114]. Regarding the genetic variations in pre-miRNA, the overexpression of miR-34a was associated with cell apoptosis and the impairment of insulin secretion due to p53 activation [174]. Finally, the variations in regulatory regions affect the transcription initiation of miRNA encoding genes, altering the expression of miRNAs. Let-7 is involved with the regulation of the synthesis and secretion of insulin. Indeed, let-7 knockdown in high-fat mice was associated with improved insulin sensitivity in target tissues [175]. By the prediction analysis, it was demonstrated that a genetic variant polymorphism (rs1143770) in a regulatory region of miRNA let-7a-2 is associated with diabetic nephropathy. The proposed mechanism to explain the finding is based on the commitment of the transcription factor cyclic adenosine monophosphate response element-binding protein (CREB), which is associated with a susceptibility to diabetic nephropathy [176]. Insulin resistance is related to the diverse complications of T2D and chronic inflammation also contributes to altering the miRNA function and expression. 
MiR-129 was expressed at a lower level in impaired fasting glucose patients and T2DM, however, the specific polymorphism associated is still unknown [127].

Wang and colleagues (2015) evaluated the possible association of genetic polymorphisms in miR-27a, miR-146a, and miR-124a with T2D [177]. Although no significant correlations were detected between the selected genotypes and T2D development, the authors found correlations between a miR-27a SNP (rs895819) and a miR-124a SNP (rs531564) with T2D associated with being overweight, while a protective effect of rs531564 in miR-124a was described. Altogether, these findings reinforce the role of miRNA polymorphisms in T2D and the relevance of environmental factors in association with miRNA polymorphisms to determine the disease development.

\section{MiRNAs and Obesity}

Obesity is considered an inflammatory disease that contributes to the development of SAH, T2D and coronary heart disease [178]. Different miRNAs participate in the adipogenesis process and modulate signaling pathways related to cell proliferation and differentiation, insulin sensitivity, and lipid metabolism [179]. Other miRNAs may be involved with inflammatory processes in obesity, either in the adipose tissue or systemically (Figure 3).
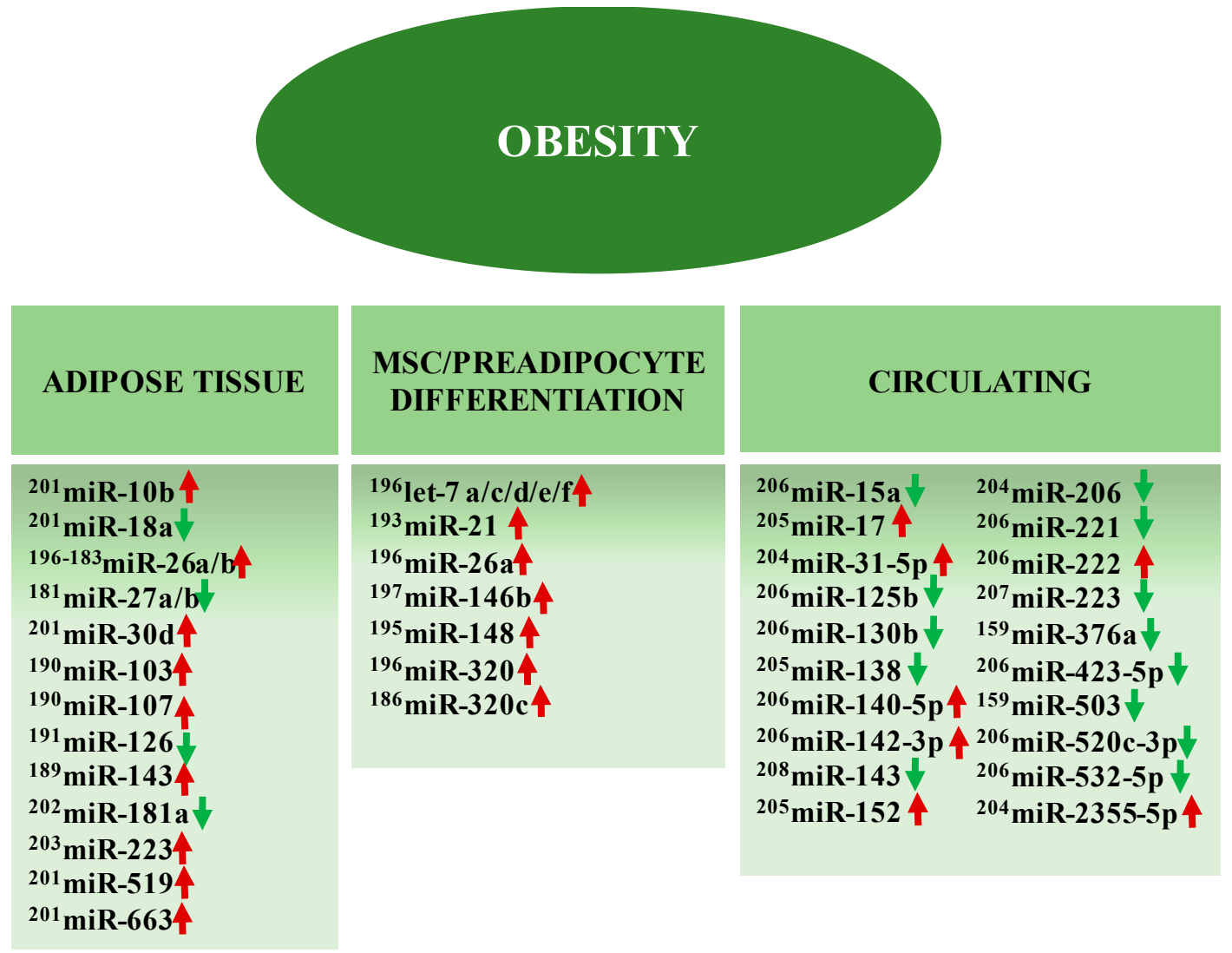

Figure 3. The dysregulated miRNA profile in obesity. The diagram shows the miRNA expression pattern found in the adipose tissue and during MSC/preadipocyte differentiation. Circulating miRNAs evaluated in serum, plasma, whole-blood, or mononuclear cells, in clinical studies, are also listed. $\uparrow=$ upregulated, $\downarrow=$ downregulated.

\subsection{MiRNAs Involved with Adipocyte Differentiation and Proliferation}

During the process of adipocyte differentiation and proliferation, the expression of miR-27a and $27 \mathrm{~b}$ is reduced, while Peroxisome proliferator-activated receptor $\gamma$ (PPAR $\gamma$ ), one of their targets is, in turn, overexpressed $[180,181]$. PPAR $\gamma$ is a member of nuclear receptors that regulate the transcription of several genes associated with obesity and diabetes [182]. It stimulates adipocyte differentiation and 
proliferation in order to increase reserves of fat in the adipose tissue. It also promotes the activation of LPL in adipose tissue, which decreases the amount of free fatty acids (FFA) present in plasma lipoproteins by capturing these lipids and storing them in adipose tissue in the form of triacylglycerol. In this way, FFA decreases, while the sensitivity of the insulin receptor increases.

MiR-26a and miR-26b, along with other microRNAs, are involved in adipocyte differentiation and proliferation [181,183-187]. The increased expression of miR-26a and miR-26b leads to the downregulation of phosphatase and tensin homologue (PTEN), which inhibits the AKT/PKB signaling pathway, impairing GLUT translocation. The deletion, mutation, or reduction of PTEN has several clinical implications, including insulin sensitivity and obesity [188]. Other miRNAs, including miR-103, miR-107, and miR-143, regulate hepatic insulin sensitivity in obese individuals through different mechanisms $[189,190]$.

MiR-126 was found to be downregulated in obesity and this may be involved in several processes since one of its targets in adipocytes is PI3KR, a PI3K inhibitor. PI3K is involved in the insulin signaling cascade, leading to the increased survival of adipose cells by the activation of the IGF-1 pathway. EVs released by adipose tissue-derived stem cells from obese patients presented reduction proangiogenic potential mainly due to the abnormalities of EVs contents, such as a reduction in VEGF, MMP-2, and miR-126 [191]. This miRNA further modulates homeostasis and vascular integrity through the RAF1/ERK signaling pathway and also modulates the expression of SPRED1, which has inhibitory actions to RAF1. Thus, SPRED1 is increased in obesity and reduces angiogenesis and vascular integrity, which may contribute to endothelial dysfunction. Indeed, by blocking miR-126 in endothelial cells' derived EV, the authors demonstrated that proangiogenic effects-endothelial cell migration and proliferation-were lost [192]. Interestingly, authors demonstrated that high-glucose reduces miR-126 expression.

MiR-21 is upregulated during the adipogenic differentiation of human adipose tissue-derived mesenchymal stem cells (MSCs), being associated with the TGF- $\beta$ pathway [193], and was also shown to be a target for weight reduction in vivo [194]. MiR-148 was found to be overexpressed in adipose tissue of high fat-fed mice and obese human subjects, promoting adipogenesis in MSCs by targeting Wnt1 $[187,195]$. Increased expression levels of members of the let-7 family, miR-26a and the miR-320 family were found during adipocyte differentiation [196]. Interestingly, the overexpression of miR-320c in MSCs enhanced the adipogenic differentiation and accelerated formation of mature adipocytes by inhibiting the Runt-related transcription factor 2 (RUNX2) [186].

MiR-146b levels in fat tissue samples from overweight or obese groups were higher when compared to the lean group [197]. MiR-146b is highly expressed in mature adipocytes, and its expression varies with the stage of the adipocytes development. MiR-146b inhibits the in vitro proliferation of visceral pre-adipocytes and promotes their differentiation by the inhibition of the transcription factor KLF7, which is an inhibitor of adipogenesis [197]. KLF7 inhibits the expression of the adipogenic transcription factors C/EBPa and PPARc and adipocyte-marker genes, such as the AP2 gene. Furthermore, KLF7 regulates the adipocytokine gene expression in mature adipocytes, inhibiting insulin secretion in pancreatic $\beta$-cells and suppressing the hexokinase 2 gene expression in muscle cells, affect insulin sensitivity [198]. Interestingly, C/EBPa has been associated with pancreas b cell apoptosis induced by pro-inflammatory cytokines [199]. These data suggest that KLF7 has a role in the pathogenesis of T2D [200].

The analysis of samples of subcutaneous adipose tissue revealed the increased expression of miR-519, and the decreased expression of the predicted target peroxisome proliferator-activated-receptor $\alpha(\operatorname{PPAR} \alpha)$, impairing FFA oxidation. In vitro studies demonstrated that miR-519d increased lipid accumulation during adipocyte differentiation. While miR-519d, miR-10b, miR-663, and miR-30d were found to be increased in the adipose tissue, miR-18a was underexpressed [201].

Inflammatory processes in obesity are closely linked to insulin resistance, T2D, and cardiovascular disease. TLR/NFKB (Toll like receptor/Nuclear Factor $\mathrm{kB}$ ) signaling in monocytes is regulated by miR-181a, $-181 \mathrm{~b}$, and $-181 \mathrm{~d}$. In obese subjects, the decreased expression of these miRNAs was found 
in monocytes, which was reversed with body weight loss. Although these miRNAs were identified as regulators of the TLR/NFKB pathway, only miR-181a had a significant correlation with metabolic syndrome and coronary artery disease [202]. In the opposite direction, miR-223 seems to exert a suppressive effect on the inflammatory cascade in visceral adipose tissue macrophages, probably as a compensatory adaptation to the inflammatory status [203].

\subsection{Other Circulating miRNAs in Obesity}

The altered expression of different circulating miRNAs has been described in obese subjects. Comparing obese and normal weight individuals, three circulating miRNAs were found differentially expressed: miR-31-5p, miR-2355-5p, and miR-206 [204]. Serum levels of miR-138, miR-376a, and miR-503 distinguish obese subjects from obese-T2D and T2D subjects [159]. Another study reported increased serum levels of miR-152 and miR-17, and a decreased level of miR-138 in obese patients when compared to the controls [205]. Plasma samples were used for the evaluation of miRNA expression profile in subjects submitted to bariatric surgery. Increased levels of miR-222, miR-140-5p, and miR-142-3p and decreased levels of miR-532-5p, miR-125b, miR-130b, miR-221, miR-15a, miR-520c-3p, and miR-423-5p, were found in obese subjects, and showed a strong association with fat mass measures. Additionally, 14 circulating miRNAs were modulated upon surgery-induced weight loss [206]. The MiR-223 levels were lower in both overweight and obese subjects, when compared to normal-weight controls, and were increased after lifestyle change and weight loss [207]. In addition to miR-223, the circulating levels of miR-143 were also significantly lower in obese subjects [208].

\subsection{Single Nucleotide Polymorphisms and miRNAs in Obesity}

Obesity is considered a low-grade chronic inflammation state and studies investigating the role of cytokine gene polymorphisms have been investigated. IL-18, a pro-inflammatory cytokine member of the interleukin-1 family, is elevated in obesity and acts in conjunction with other cytokines, including IL-1, to activate the NFKB and transcription activator-1, modulating the expression of inflammatory genes [209-212]. The IL-18 actions depend on binding to its heterodimeric receptor IL-18R, composed by the IL-18R1 chain, with a binding function, and the IL18RAP chain, involved in signal transduction [213]. Martínez-Barquero et al. (2017) investigated the association between the IL18RAP gene polymorphisms, body mass index, and obesity [214]. They selected five SNPs in the IL18RAP that could change the miRNA-136 binding site. MiR-136 is associated with adipogenic differentiation and is involved in appetite control and energy homeostasis in hypothalamic neurons [215-217]. The rs7559479 $\mathrm{G}$ allele has a high association with obesity and the body mass index which augments the susceptibility to obesity. On the other side, the rs7559479 A allele was associated with an increased miR-136 binding to IL18RAP, enhancing IL-18 signaling.

As mentioned before, the genetic polymorphisms of the 3'-UTR in microRNA target genes may change the microRNA binding sites. Richardson et al. (2011) evaluated the association of SNPs and obesity, demonstrating the role of the creation of a new regulatory site to miRNA due to these SNP in disease development [218]. These studies demonstrated the association between obesity and SNPs at human PLIN4/S3-12, which is a member of the PAT (perilipin, adipose differentiation-related protein (ADRP), and tail-interacting protein of 47 kilodaltons-TIP47) Family lipid storage droplets (LSDs). It was described that a series of anthropometric characteristics found in obese people were modulated through a diet enriched in polyunsaturated fatty acids. The mechanism proposed is that $P A T$ genes respond to a hyperlipidic diet at the transcriptional level, since polyunsaturated fatty acids are ligands of peroxisome proliferator-activated receptor (PPAR) whose response-elements (PPREs) are expressed in the promoter regions of PLIN1 and PLIN4 [219]. The results pointed to the relevance of the rs 8887 A allele in creating a new binding site specifically to miR-522 that promoted the reduction in PLIN4 protein levels. These finding demonstrated the effects of the association of genetic factors with environmental factors in the susceptibility to obesity development. 
Another key regulatory element in the lipid metabolism is a serine hydrolase known as Butyrylcholinesterase (BChE; EC 3.1.1.8), which is related to metabolic syndrome risk in obese patients [220]). In these individuals, the BChE expression is higher than in lean subjects, probably due to the elevated free fatty acid (FFA) circulating levels [221]. BChE gene polymorphisms have been reported before in, for example, the study conducted by Lima and colleagues (2013), in which the role of the 1914G allele of $B C h E$ gene in metabolism was investigated [222]. This allele represents a site of different microRNAs, including hsa-miR-498 and hsa-miR-662, regulating the BChE expression and activity, leading to alterations in different metabolic pathways and contributing to the development of obesity. These findings demonstrate that SNPs in a variety of genes involved in the metabolism may affect homeostasis, being exacerbated by environmental factors.

\section{Overlapping miRNAs in SAH, T2D, and Obesity}

After the review of miRNAs associated with SAH, T2D, and obesity, it was possible to find 144 miRNAs with an altered expression in experimental and clinical studies. Although considerable variability was found in terms of design, sample, and methodology, it was possible to identify 16 miRNAs with an altered expression that overlapped between T2D and SAH, 19 between T2D and obesity, and 15 between obesity and SAH. We also found 8 miRNAs-miR-21, miR-27a, miR-30d, miR-126, miR-143, miR-181a, miR-222, and miR-223-that overlapped between the three diseases (Figures 4 and 5).

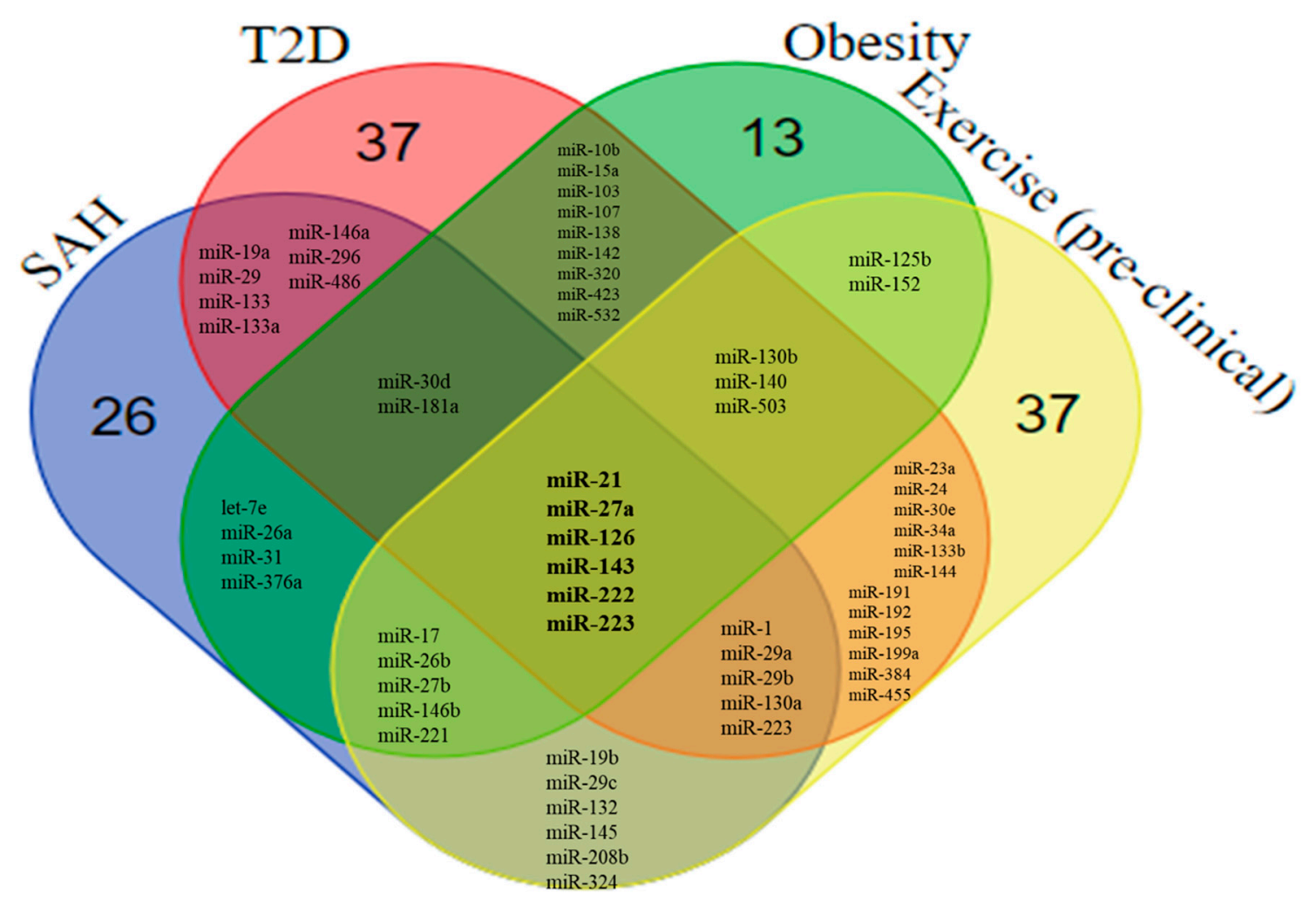

Figure 4. A Venn diagram of hypertension, diabetes, obesity, and their overlapping with exercises (pre-clinical). The Venn diagram was used to identify overlapping and non-overlapping miRNAs in the analysis of studies on the microRNA profile of expression in cardiometabolic diseases and pre-clinical studies on exercise training. 


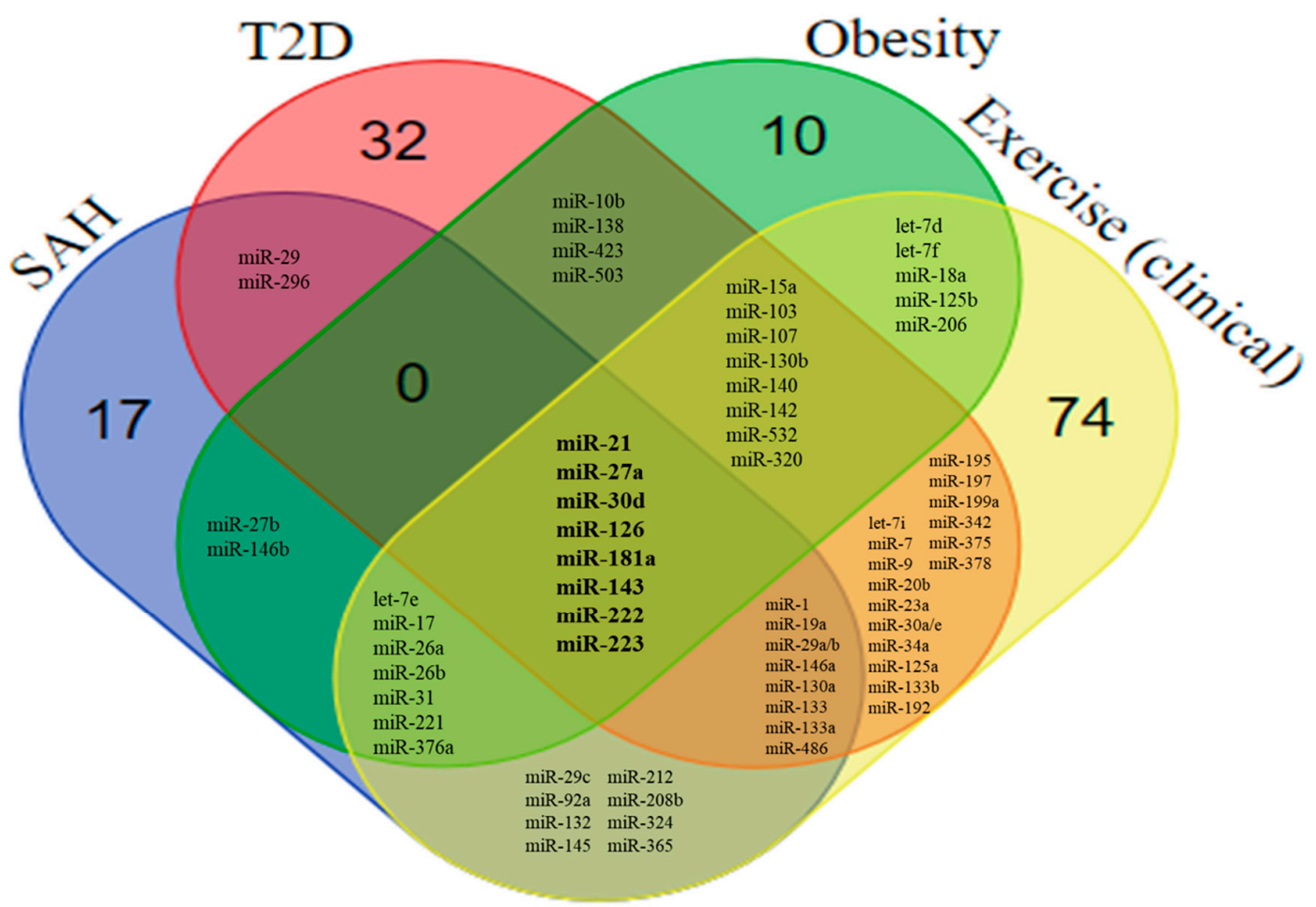

Figure 5. A Venn diagram of hypertension, diabetes, obesity, and their overlapping with exercises (clinical). The Venn diagram was used to identify overlapping and non-overlapping miRNAs in the analysis of studies on the microRNA profile of expression in cardiometabolic diseases and clinical studies on exercise training.

MiR-21 was upregulated in SAH, T2D, and obesity, both in experimental and in clinical studies, suggesting a potential role in the common aspects of the disease pathogenesis. MiR-21 is highly expressed in VSMCs, endothelial cells, cardiomyocytes, and cardiac fibroblasts, acting on different targets, including PDCD4 (programmed cell death protein 4), PTEN (phosphatase and tensin homolog protein), SPRY1 (protein sprouty homolog 1), and SPRY2 (protein sprouty homolog 2) [19], being associated with apoptosis, inflammation, and participating in VEGF and TGF- $\beta$ signaling pathways. MiR-21 has also a role in the promotion of cardiac hypertrophy [223].

The underexpression of miR-126 is consistently reported in the context of SAH, T2D, and obesity in both experimental and clinical studies. Under physiological conditions, miR-126 is highly expressed in endothelial cells, being involved in angiogenesis and with anti-inflammatory actions. MiR-126 regulates the expression of the chemokine (C-C motif) ligand 2 (CCL2) [35], which has been associated with the recruitment of inflammatory cells and insulin resistance [224]. Likewise, VCAM-1, which is involved in leukocyte-endothelial cell adhesion and may play a role in the development of atherosclerosis, is down-regulated by miR-126 under physiological conditions. By reducing the VCAM- 1 expression, miR-126 led to a decreased vascular inflammation due to a reduced interaction between leukocytes and endothelial cells [54]. Moreover, reduced miR-126 expression impairs angiogenesis and vascular integrity through the inhibition of PI3KR2 [51].

Data from clinical studies revealed the increased expression of circulating miR-222 in SAH, T2D, and obesity. MiR-222 participates in several physiological functions in the cardiovascular system and an increasing body of data has pointed to a protective role played by miR-222, promoting angiogenesis and regulating physiological functions of cardiomyocytes [225].

MiR-223 was found to be increased in the adipose tissue in obesity, working as a compensatory anti-inflammatory molecule, but with a reduced expression in the circulation of obese and T2D subjects [203]. Additionally, the experimental data suggest that miR-223 could be increased in SAH, but there are no clinical validation studies available so far. 
Circulating levels of miR-143, which targets angiotensin converting enzyme (ACE), were reduced in hypertensive, obese, and T2D subjects in one study. There is evidence, however, that the tissue overexpression of miR-143 contributes to insulin resistance in T2D [226]. The tissue overexpression of miR-143 was also found in different experimental models of diabetes in mice, with a negative regulation of insulin-mediated AKT activation [227].

Different studies have reported reduced circulating levels of miR-181a both in T2D and obesity, while increased levels have been reported for hypertensive patients [89]. The opposite pattern was found for miR-30d, with increased circulating levels in T2D and obesity, and reduced levels in SAH $[99,141,201]$. MiR-27a was increased and associated with hyperglycemia and metabolic syndrome in T2D patients, also playing a role in adipogenesis and in the regulation of blood pressure [228].

Currently, it is not completely understood whether the reported miRNAs are involved in the early or advanced aspects of the disease pathogenesis. Further studies are needed in order to define the roles of individual miRNAs and their targets in different disease settings, tissues, and diseases. MiRNAs with differential expression could potentially be applied as biomarkers for diagnosis, prognosis, risk stratification, or even be therapeutically targeted. Nevertheless, this would require larger validation studies, considering that the studies performed vary significantly in terms of design.

\section{Exercise and Cardiovascular Protection}

Exercise training is a classical recommendation for patients with cardiometabolic diseases and The American Heart Association recommends at least $30 \mathrm{~min}$ of aerobic exercise five days a week in order to promote cardiovascular risk reduction [229]. Aerobic exercise training is able to ameliorate dyslipidemia, insulin resistance, endothelial function, and inflammatory status [230]. It is well known that exercise training exerts beneficial effects in healthy [231] and in individuals with SAH [232], T2D [233], obesity [234,235], cancer [236], coronary heart disease [237], and chronic heart failure [238].

Aerobic exercise training induces a physiological eccentric cardiac hypertrophy, while resistance training promotes a physiological concentric hypertrophy [239]. The experimental data suggest that exercise training may counteract the pathological cardiac remodeling, decreasing fibrosis, and improving heart function [240,241]. Anti-remodeling actions of exercise training were previously demonstrated in subjects with heart failure [242] and also in experimental models of myocardial infarction and diabetes [241,243]. Little is known about the mechanisms and molecular pathways involved in the anti-remodeling actions of exercise training. One of the mechanisms suggested to explain the exercise-mediated regulation of cellular homeostasis is through modulation in the miRNA expression profile.

\subsection{Altered miRNA Expression Induced by Exercise Training}

Cellular homeostasis is affected by exercise, with influences in the circulating miRNA signature. These alterations in the circulating miRNA profile are dynamic and change significantly during the acute response and chronic adaptation to exercise [244]. Different cell types may be involved in the release of miRNAs into the circulation immediately after acute exercise, which probably reflects exercise-induced tissue stress or damage [245]. Moreover, tissue analyses have clearly demonstrated the effects of different types of exercise in the miRNA profile in the vasculature, heart, and skeletal muscles.

In addition to the study of miRNA dysregulation in SAH, T2D, and obesity, the influence of exercise training in the expression of miRNAs in pre-clinical and clinical studies was also reviewed (Tables S1 and S2). Considerable variation in the results was found, and this can be attributed to the variation in methods, protocols and other aspects of individual variation, such as age, sex, ethnicity, and genetic background.

\subsection{Overlaps Between the miRNA Profile in SAH, T2D, Obesity, and Exercise}

The beneficial effects of exercise training in miRNA-mediated gene regulation in the population of patients with SAH, T2D, and obesity are currently unexplored since the majority of clinical studies 
focus on healthy subjects. Identification of miRNAs regulated by exercise in diseased subjects would be important to understand the dynamic alterations and protective roles exerted by exercise training in the context of cardiovascular diseases. In our review, 76 miRNAs with altered expression induced by exercise were described in the experimental models, while 141 were found in clinical studies (Table S1). By comparing the expression profile of these miRNAs with the miRNAs reviewed in the context of SAH, T2D, and obesity, we found significant overlaps (Figures 4 and 5). Among the miRNAs evaluated in the experimental models, we found miR-21, miR-27a, miR-126, miR-143, miR-222, and miR-223 in common with all three diseases (Figure 4). In addition to these miRNAs, miR-30d and miR-181a were also reported to be altered in clinical studies (Figure 5).

Pre-clinical studies reported that miR-21 is increased in the heart after a chronic adaptation to exercise [246,247]. Non-pathological left ventricular hypertrophy is a normal adaptation of exercise training and increased miR-21 expression may be involved in this process [248]. Meanwhile, in clinical studies, there is considerable variability regarding the circulating levels of miR- 21 in healthy subjects submitted to different protocols of exercise training. Radom-Azik and colleagues reported increased miR-21 levels in the PBMCs during the acute response to cycle ergometer exercise [249], while Baggish and colleagues reported increased circulating miR-21 in serum samples during both the acute and chronic response after rowing training $[250,251]$. In chronic heart failure subjects, however, acute exhaustive exercise-induced an increase in the serum levels of miR-21, suggesting its potential role in the adaptation to exercise [252]. An opposite regulation of miR-21 was reported in the acute phase and chronic response to exercise training. Baggish and colleagues found increased levels of miR-21 in the acute phase [250], while Nielsen and colleagues reported the underexpression of miR-21 in the plasma after a chronic adaptation to cycling ergometer training [244]. This variability may also be explained by the diversity of exercise training protocols, the type of samples used in the analyses, and also by the small sample sizes, with no more than 32 subjects included in each study.

MiR-27a and miR-27b were reduced during adipogenesis [181], while exercise increased their expression $[239,253]$. The increased expression of miR-27a and miR-27b could be involved in the control of body mass [254]. The gene coding PPAR $\gamma$, which plays roles in the adipocyte differentiation, is a target of miR-27a [254]. Therefore, its inhibition promoted by the increased expression of miR-27a following exercise training could be involved in the control of body mass. Pre-clinical studies reported that miR-27a is increased in skeletal and cardiac muscle after acute and chronic training $[255,256]$. In a clinical study, the evaluation of circulating levels of miRNAs demonstrated decreased plasma levels of miR-27a in obese subjects in the acute and chronic response of exercise training [230]. Increase miR-27a expression was found in rats after swimming training [256].

Pre-clinical studies have reported increased miR-126 expression in the myocardium after a chronic exercise training adaptation $[257,258]$. Clinical studies have focused on the acute response to different protocols of exercise training in healthy subjects, where decreased levels of miR-126 were reported in PBMCs $[249,259]$. Two studies, however, reported increased miR-126 levels in the plasma of healthy men after marathon runs [251,260]. The induction of increased levels of miR-126 by exercise could counteract the underexpression found in obesity, $\mathrm{SAH}$, and T2D.

MiR-143 was found to be reduced in the heart, experimentally, after a chronic adaptation to exercise training [261]. In clinical studies, however, aerobic training induced an acute increase in miR-143 circulating levels [244,262]. The miR-143/miR-145 gene cluster, which negatively regulates the ACE gene expression, is a regulator of the contractile phenotype of VSMCs [10]. In contrast, in exercise, these miRNAs presented an increased expression $[244,246]$. The difference status in their expression indicates that this could be one important mechanism of blood pressure control induced by exercise. Experimental studies suggest that ACE2 is important for cardiovascular function [263] and, in spontaneously hypertensive rats, chronic aerobic exercise training was associated with increased levels of miR-27a (targeting ACE) and decreased levels of miR-143 (targeting ACE2), contributing to blood pressure regulation [264]. Aerobic exercise training could induce a nonpathological left ventricular hypertrophy, altering the expression of miRNAs that regulate RAAS genes [256]. 
Interestingly, miR-21 and miR-143 showed a different response when evaluated after acute and chronic training. Increased levels of miR-143 were observed $1 \mathrm{~h}$ after acute exercise [244] and decreased in chronic training [256]. Increased levels of circulating miR-21 were observed in response to acute aerobic exercise and decreased levels in chronic training [244]. It is possible that the acute increase in miR-21 may be involved in inflammation [265], while regular exercise exerts long-term anti-inflammatory effects, correlating with decreased miR-21 levels in the chronic adaptation phase [244].

It was demonstrated that miR-126 increased after 10 weeks of training based on swimming [258], which could contribute to the report of balanced angiogenic and apoptotic factors and the normalization of VEGF, eNOS, and PI3KR2 levels observed after exercise training in hypertensive rats [266]. The MiR-126 expression has been demonstrated to be associated with angiogenesis, anti-inflammatory response, and atherosclerosis [267]. MiR-126 negatively regulates the expression of the CCL2 gene [35], which is involved in the development of the obesity-induced inflammation and insulin resistance in the skeletal muscle [224]. MiR-126 also reduces vascular inflammation by decreasing interactions between leukocytes and endothelial cells and diminishing the production of inflammatory mediators [54,268].

The cardiac expression of miR-222 was increased in the acute response after exercise in an experimental study [269] and was also increased in the serum of both the acute and chronic phase after exercise training in healthy subjects [250]. Interestingly, miR-222 was also found to be acutely increased in plasma samples of subjects with chronic heart failure submitted to aerobic training by a bicycle ergometer test [269]. MiR-223 is also increased in the circulation of healthy subjects during the acute response after exercise training, while upregulation was described in the heart tissue after chronic aerobic training in a preclinical study $[248,262,270]$.

\subsection{SAH vs. Exercises: miRNAs Differentially Expressed}

Aerobic training has been implicated as an important nonpharmacological treatment for hypertension [266]. The protective effects of physical training in vascular pathological alterations have been reported to occur through the regulation of miRNAs. Different miRNAs with descriptions of opposite expression profiles in SAH and exercises were described in the literature and are described below (Figure 6).

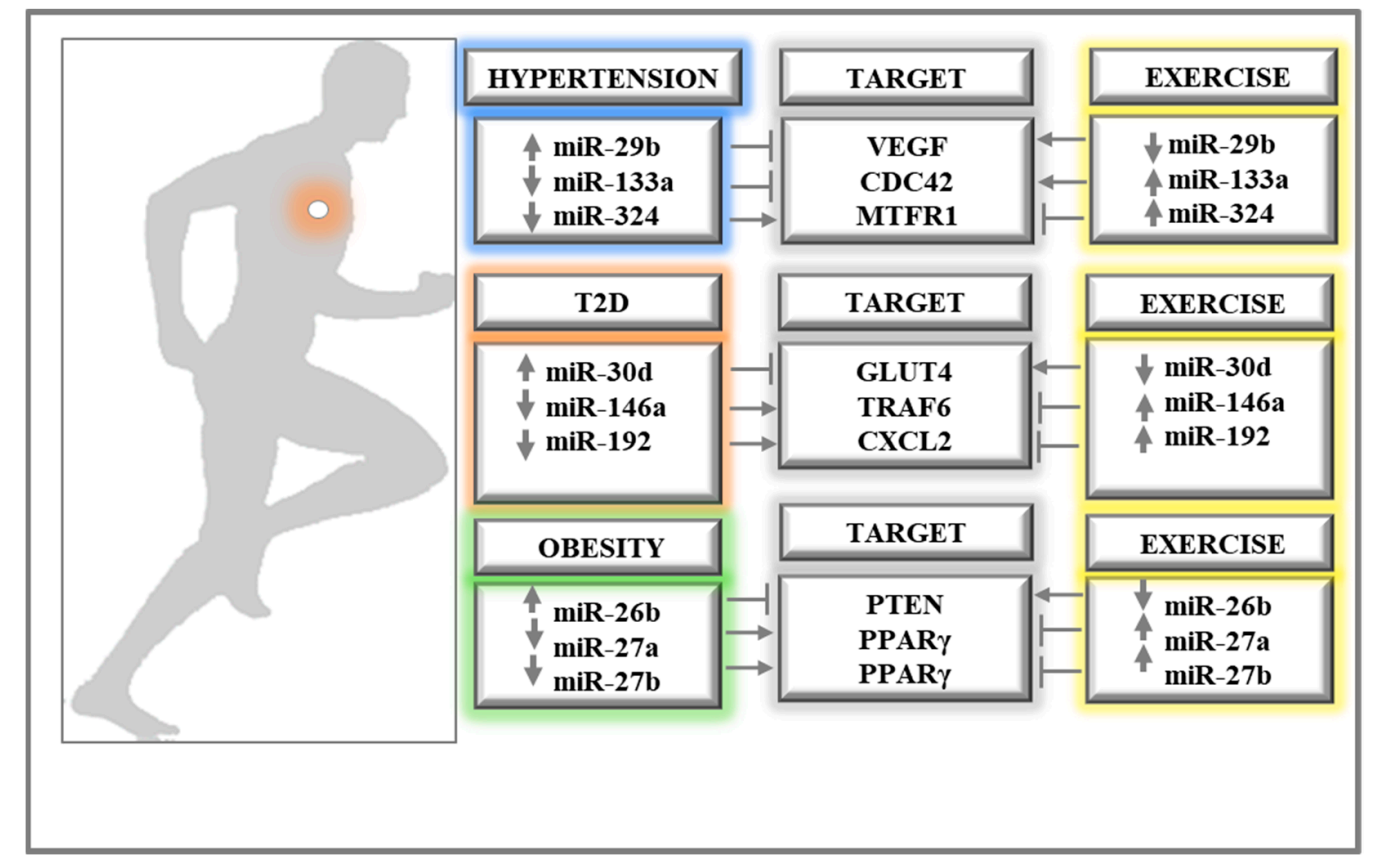

Figure 6. The opposite regulation of miRNA expression after exercises and their targets. The scheme illustrates examples of miRNAs with differential expression reported for diseases and exercise training. The respective gene target is also indicated. $\uparrow=$ upregulated, $\downarrow=$ downregulated. 
Increased levels of miR-146a and miR-126 along with reduced miR-155 levels were found on the aorta of mice with atherosclerosis after 12-week aerobic exercise [271]. Increase levels of miR-16, miR-21, and miR-126 were found in the muscles of hypertensive rats after 10 weeks of swimming, correlating with a balance between angiogenic and apoptotic factors [272]. Interestingly, miRNAs regulating the gene of ACE were differentially expressed in both hypertension and exercise, like the exercise-induced increase of miR-27a (targeting ACE) and miR-155 (targeting AT1R) and the decrease of miR-143 (targeting ACE2) [264]. Plasma levels of miR-92 increased in hypertensive patients, correlating with the blood pressure levels [96], while it was described to be reduced during chronic adaptation to exercise training [244].

MiR-29b was highly expressed in SAH [97] and indirectly regulates the expression of the VEGFA and COL1A2 genes. Interestingly, exercise reduces miR-29b expression [231], suggesting that this process may be involved in the amelioration of the endothelial function promoted by exercise.

MiR-19b, which was found downregulated in SAH, was reported to be increased by exercise training in pre-clinical and clinical studies $[273,274]$. Other miRNAs presented opposite expressions between SAH and exercise. This is the case of miR-324, which was found reduced in SAH [99] and increased by aerobic exercise training, both experimentally [253] and in human subjects [275]. This finding could be associated with cardioprotective actions since miR-324 regulates mitochondrial fission and apoptosis by targeting Mtfr1, leading to a suppression of cardiomyocyte death and myocardial infarction [276].

The downregulation of miR-133a is involved in the process of cardiac hypertrophy since miR-133a indirectly targets anti-hypertrophic genes [277]. The MiR-133a expression levels were reduced in SAH, while circulating levels were increased in healthy subjects after exercise training [244,251,278,279]. Interestingly, the miR-133a overexpression prevents cardiac fibrosis in a mouse model of diabetic cardiomyopathy [280]. In contrast, miRNA-22 is overexpressed in SAH, being involved in the sympathetic nervous system hyperactivation, and reduced by exercise [95,273].

\subsection{T2D versus Exercises: miRNAs Differentially Expressed}

Different miRNAs with descriptions of opposite expression profiles in T2D and exercises were described (Figure 6). MiR-192 was found to be reduced in T2D patients [146] and increased in heart samples of rats after chronic adaptation to exercise [253]. Moreover, increased levels of miR-192 were found after acute exercise training in humans [259]. This miRNA regulates the CXCL2 gene, which is part of a superfamily of chemokines associated with inflammation and, therefore, could contribute to the inflammatory response associated with T2D [281]. Since miR-192 can inhibit CXCL2 activity, this process could be involved in the anti-inflammatory properties of exercise, which can be beneficial in T2D patients.

Corroborating with this hypothesis, other miRNAs involved in the regulation of inflammation are differentially expressed between T2D and exercise training, including miR-146a. Clinical studies have demonstrated that circulating levels of miR-146a can be found either upregulated or downregulated in T2D patients [282,283], while two independent reports described that aerobic exercise training can increase miR-146a levels $[250,251]$. Resistance exercise training, however, was found to acutely decrease miR-146a expression in healthy subjects [284]. One of the targets of miR-146a is TRAF6, a member of the TNF receptor-associated factor protein family and mediates the signal transduction of TNF receptors. Additionally, the protein encoded by TRAF6 gene is a signal transducer and participates in the pathway that activates IkappaB kinase (IKK) in response to proinflammatory cytokines [285]. Notably, increased levels of miR-146a induced by exercise may contribute to the modulation of the chronic inflammatory response in T2D. MiR-24 is another miRNA with anti-inflammatory actions that was found downregulated in the circulation of T2D patients [144,286]. In an experimental study, exercise training was associated with increased cardiac expression of miR-24 [253].

MiR-144 is overexpressed in T2D and regulates the IRS, the initiator of insulin signaling [127,128]. This is one of the molecular mechanisms leading to insulin resistance. Studies diverge about the 
exercise-induced response, with reports of both increased and decreased expression of miR-144 [246,253]. Further studies with clinical validations are needed to analyze the effects of physical exercise on the expression of miR-144. MiR-9 negatively affects the process of insulin secretion by targeting Onecut2, and has been found to be overexpressed in T2D, being downregulated in the skeletal muscle, in the acute response to ergometer cycle [287]. MiR-384 is involved in insulin resistance, impairing the GLUT4 translocation to the cell surface by targeting the PI3K/AKT axis, and was found to be increased in T2D and decreased in the heart after chronic exercise training in rats [253].

\subsection{Obesity vs. Exercises: miRNAs Differentially Expressed}

Other miRNAs were found with opposite expression between obesity and exercise training (Figure 6), including miR-26a, miR-27b, and miR-206. The MiRNA-26 family is also important to adipogenesis and their inhibition reduces lipid accumulation, while their overexpression increases it $[183,184,186,187]$. Exercise can reduce the expression of miR-26a after aerobic [231] and resistance exercises [288]. MiR-27b targets PPAR $\gamma$, being reduced in obesity and increased after exercise [253,256]. MiR-206, which was shown to block adipogenesis [289], is reduced in the circulation of obese subjects, and increased after marathon runs in healthy subjects [290].

\section{Conclusions}

MiRNAs are involved in the pathogenesis of cardiometabolic diseases and common regulatory pathways can be identified in SAH, T2D, and obesity. Exercise training modulates the expression of several miRNAs-both in the short-term and in long-term - which act by regulating targets that affect different key cellular and molecular processes, frequently in the opposite direction to that described to be involved in the pathogenesis of cardiometabolic diseases. Further validation studies are needed to evaluate the cellular and molecular effects of exercise training in these diseases and to confirm the ability of exercise training to ameliorate the altered miRNA expression profile found in patients with cardiometabolic diseases, especially regarding long-term effects. Additionally, the identification of miRNAs beneficially modulated by exercise training can contribute to the development of new drugs and therapies for the treatment of SAH, T2D, and obesity.

Supplementary Materials: Supplementary materials can be found at http:/ / www.mdpi.com/1422-0067/19/ $11 / 3608 / s 1$. References [231,234,241,244,246-251,253-262,269,273-275,278,279,284,287,288,290] are cited in the supplementary materials.

Author Contributions: Author Contributions: A.C.I.C., C.S.P. and S.G.M. formulated the theme and outline of the review. A.C.I.C., C.S.P., B.S.d.F.S. and C.K.V.N. reviewed the literature and drafted and revised the manuscript. B.S.d.F.S, M.B.P.S., and S.G.M. reviewed, revised, and finalized the manuscript.

Funding: This research received no external funding.

Acknowledgments: The authors acknowledge Mirela Caria for graphic support.

Conflicts of Interest: The authors declare no conflict of interest.

\section{References}

1. Ha, M.; Kim, V.N. Regulation of microRNA biogenesis. Nat. Rev. Mol. Cell Biol. 2014, 15, 509-524. [CrossRef] [PubMed]

2. Griffiths-Jones, S.; Saini, H.K.; Van Dongen, S.; Enright, A.J. miRBase: Tools for microRNA genomics. Nucleic Acids Res. 2008, 36, D154-D158. [CrossRef] [PubMed]

3. Chiang, H.R.; Schoenfeld, L.W.; Ruby, J.G.; Auyeung, V.C.; Spies, N.; Baek, D.; Johnston, W.K.; Russ, C.; Luo, S.; Babiarz, J.E.; et al. Mammalian microRNAs: Experimental evaluation of novel and previously annotated genes. Genes Dev. 2010, 24, 992-1009. [CrossRef] [PubMed]

4. Kozomara, A.; Griffiths-Jones, S. miRBase: Annotating high confidence microRNAs using deep sequencing data. Nucleic Acids Res. 2014, 42, D68-D73. [CrossRef] [PubMed]

5. Bartel, D.P. MicroRNAs: Target recognition and regulatory functions. Cell 2009, 136, 215-233. [CrossRef] [PubMed] 
6. Baek, D.; Villén, J.; Shin, C.; Camargo, F.D.; Gygi, S.P.; Bartel, D.P. The impact of microRNAs on protein output. Nature 2008, 455, 64-71. [CrossRef] [PubMed]

7. Huntzinger, E.; Izaurralde, E. Gene silencing by microRNAs: Contributions of translational repression and mRNA decay. Nat. Rev. Genet. 2011, 12, 99-110. [CrossRef] [PubMed]

8. Muljo, S.A.; Kanellopoulou, C.; Aravind, L. MicroRNA targeting in mammalian genomes: Genes and mechanisms. Wiley Interdiscip. Rev. Syst. Biol. Med. 2010, 2, 148-161. [CrossRef] [PubMed]

9. Kawai-Kowase, K.; Owens, G.K. Multiple repressor pathways contribute to phenotypic switching of vascular smooth muscle cells. Am. J. Physiol. Cell Physiol. 2007, 292, C59-C69. [CrossRef] [PubMed]

10. Boettger, T.; Beetz, N.; Kostin, S.; Schneider, J.; Krüger, M.; Hein, L.; Braun, T. Acquisition of the contractile phenotype by murine arterial smooth muscle cells depends on the Mir143/145 gene cluster. J. Clin. Investig. 2009, 119, 2634-2647. [CrossRef] [PubMed]

11. Gong, W.; Xiao, D.; Ming, G.; Yin, J.; Zhou, H.; Liu, Z. Type 2 diabetes mellitus-related genetic polymorphisms in microRNAs and microRNA target sites. J. Diabetes 2014, 6, 279-289. [CrossRef] [PubMed]

12. Pickrell, J.K.; Marioni, J.C.; Pai, A.A.; Degner, J.F.; Engelhardt, B.E.; Nkadori, E.; Veyrieras, J.B.; Stephens, M.; Gilad, Y.; Pritchard, J.K. Understanding mechanisms underlying human gene expression variation with RNA sequencing. Nature 2010, 464, 768-772. [CrossRef] [PubMed]

13. Ryan, B.M.; Robles, A.I.; Harris, C.C. Genetic variation in microRNA networks: The implications for cancer research. Nat. Rev. Cancer 2010, 10, 389-402. [CrossRef] [PubMed]

14. Wu, C.; Gong, Y.; Sun, A.; Zhang, Y.; Zhang, C.; Zhang, W.; Zhao, G.; Zou, Y.; Ge, J. The human MTHFR rs4846049 polymorphism increases coronary heart disease risk through modifying miRNA binding. Nutr. Metab. Cardiovasc. Dis. 2013, 23, 693-698. [CrossRef] [PubMed]

15. Nyayanit, D.; Gadgil, C.J. Mathematical modeling of combinatorial regulation suggests that apparent positive regulation of targets by miRNA could be an artifact resulting from competition for mRNA. RNA 2015, 21, 307-319. [CrossRef] [PubMed]

16. Winter, J.; Jung, S.; Keller, S.; Gregory, R.I.; Diederichs, S. Many roads to maturity: MicroRNA biogenesis pathways and their regulation. Nat. Cell Biol. 2009, 11, 228-234. [CrossRef] [PubMed]

17. Selbach, M.; Schwanhäusser, B.; Thierfelder, N.; Fang, Z.; Khanin, R.; Rajewsky, N. Widespread changes in protein synthesis induced by microRNAs. Nature 2008, 455, 58-63. [CrossRef] [PubMed]

18. Rupaimoole, R.; Slack, F.J. MicroRNA therapeutics: Towards a new era for the management of cancer and other diseases. Nat. Rev. Drug Discov. 2017, 16, 203-222. [CrossRef] [PubMed]

19. Cheng, Y.; Zhang, C. MicroRNA-21 in cardiovascular disease. J. Cardiovasc. Transl. Res. 2010, 3, $251-255$. [CrossRef] [PubMed]

20. Turchinovich, A.; Weiz, L.; Langheinz, A.; Burwinkel, B. Characterization of extracellular circulating microRNA. Nucleic Acids Res. 2011, 39, 7223-7233. [CrossRef] [PubMed]

21. Vickers, K.C.; Palmisano, B.T.; Shoucri, B.M.; Shamburek, R.D.; Remaley, A.T. MicroRNAs are transported in plasma and delivered to recipient cells by high-density lipoproteins. Nat. Cell Biol. 2011, 13, 423-433. [CrossRef] [PubMed]

22. Huang, X.; Yuan, T.; Tschannen, M.; Sun, Z.; Jacob, H.; Du, M.; Liang, M.; Dittmar, R.L.; Liu, Y.; Liang, M.; et al. Characterization of human plasma-derived exosomal RNAs by deep sequencing. BMC Genomics 2013, 14, 319. [CrossRef] [PubMed]

23. Sato-Kuwabara, Y.; Melo, S.A.; Soares, F.A.; Calin, G.A. The fusion of two worlds: Non-coding RNAs and extracellular vesicles-diagnostic and therapeutic implications (Review). Int. J. Oncol. 2015, 46, 17-27. [CrossRef] [PubMed]

24. Kinoshita, T.; Yip, K.W.; Spence, T.; Liu, F.F. MicroRNAs in extracellular vesicles: Potential cancer biomarkers. J. Hum. Genet. 2017, 62, 67-74. [CrossRef] [PubMed]

25. Kim, K.M.; Abdelmohsen, K.; Mustapic, M.; Kapogiannis, D.; Gorospe, M. RNA in extracellular vesicles. Wiley Interdiscip. Rev. RNA 2017, 8, e1413. [CrossRef] [PubMed]

26. Arroyo, J.D.; Chevillet, J.R.; Kroh, E.M.; Ruf, I.K.; Pritchard, C.C.; Gibson, D.F.; Mitchell, P.S.; Bennett, C.F.; Pogosova-Agadjanyan, E.L.; Stirewalt, D.L.; et al. Argonaute2 complexes carry a population of circulating microRNAs independent of vesicles in human plasma. Proc. Natl. Acad. Sci. USA 2011, 108, 5003-5008. [CrossRef] [PubMed] 
27. Roth, G.A.; Johnson, C.; Abajobir, A.; Abd-Allah, F.; Abera, S.F.; Abyu, G.; Ahmed, M.; Aksut, B.; Alam, T.; Alam, K.; et al. Global, Regional, and National Burden of Cardiovascular Diseases for 10 Causes, 1990 to 2015. J. Am. Coll. Cardiol. 2017, 70, 23715. [CrossRef] [PubMed]

28. Go, A.S.; Mozaffarian, D.; Roger, V.L.; Benjamin, E.J.; Berry, J.D.; Blaha, M.J.; Dai, S.; Ford, E.S.; Fox, C.S.; Franco, S.; et al. Executive summary: Heart disease and stroke statistics-2014 update: A report from the American Heart Association. Circulation 2014, 129, 399-410. [CrossRef] [PubMed]

29. Shah, M.S.; Brownlee, M. Molecular and cellular mechanisms of cardiovascular disorders in diabetes. Circ. Res. 2016, 118, 1808-1829. [CrossRef] [PubMed]

30. IDF Diabetes Atlas. Available online: https://www.idf.org/e-library/epidemiology-research/diabetesatlas/13-diabetes-atlas-seventh-edition.html (accessed on 29 June 2018).

31. Mandavia, C.H.; Aroor, A.R.; Demarco, V.G.; Sowers, J.R. Molecular and metabolic mechanisms of cardiac dysfunction in diabetes. Life Sci. 2013, 92, 601-608. [CrossRef] [PubMed]

32. Ogden, C.L.; Carroll, M.D.; Kit, B.K.; Flegal, K.M. Prevalence of childhood and adult obesity in the United States, 2011-2012. JAMA 2014, 311, 806-814. [CrossRef] [PubMed]

33. Rosen, E.D.; Spiegelman, B.M. What we talk about when we talk about fat. Cell 2014, 156, 20-44. [CrossRef] [PubMed]

34. Kusminski, C.M.; Bickel, P.E.; Scherer, P.E. Targeting adipose tissue in the treatment of obesity-associated diabetes. Nat. Rev. Drug Discov. 2016, 15, 639-660. [CrossRef] [PubMed]

35. Arner, E.; Mejhert, N.; Kulyté, A.; Balwierz, P.J.; Pachkov, M.; Cormont, M.; Lorente-Cebrián, S.; Ehrlund, A.; Laurencikiene, J.; Hedén, P.; et al. Adipose tissue microRNAs as regulators of CCL2 production in human obesity. Diabetes 2012, 61, 1986-1993. [CrossRef] [PubMed]

36. Tanti, J.F.; Ceppo, F.; Jager, J.; Berthou, F. Implication of inflammatory signaling pathways in obesity-induced insulin resistance. Front. Endocrinol. (Lausanne) 2013, 3, 181. [CrossRef] [PubMed]

37. Neves, V.J.; Fernandes, T.; Roque, F.R.; Soci, U.P.; Melo, S.F.; de Oliveira, E.M. Exercise training in hypertension: Role of microRNAs. World J. Cardiol. 2014, 6, 713-727. [CrossRef] [PubMed]

38. World Health Organization. WHO A Global Brief on Hypertension; WHO Press: Geneva, Switzerland, $2013 ;$ p. 40.

39. Malachias, M.; Plavnik, F.L.; Machado, C.A.; Malta, D.; Scala, L.C.N.; Fuchs, S. 7th Brazilian Guideline of Arterial Hypertension: Chapter 1-Concept, Epidemiology and Primary Prevention. Arq. Bras. Cardiol. 2016, 107, 1-6. [CrossRef] [PubMed]

40. Chalmers, J. The importance of drug combinations for effective control of hypertension. Clin. Exp. Hypertens. 1999, 21, 875-884. [CrossRef] [PubMed]

41. Lifton, R.P. Molecular genetics of human blood pressure variation. Science 1996, 272, 676-680. [CrossRef] [PubMed]

42. Turner, S.T.; Boerwinkle, E. Genetics of blood pressure, hypertensive complications, and antihypertensive drug responses. Pharmacogenomics 2003, 4, 53-65. [CrossRef] [PubMed]

43. Kroll, M.H.; Schafer, A.I. Biochemical mechanisms of platelet activation. Blood 1989, 74, 1181-1195. [PubMed]

44. Bassenge, E.; Huckstorf, C. Endothelium-dependent mechanisms of vascular regulation. Verh. Dtsch. Ges. Inn. Med. 1991, 97, 567-573. [PubMed]

45. Li, Q.; Youn, J.Y.; Cai, H. Mechanisms and consequences of endothelial nitric oxide synthase dysfunction in hypertension. J. Hypertens. 2015, 33, 1128-1136. [CrossRef] [PubMed]

46. Nemecz, M.; Alexandru, N.; Tanko, G.; Georgescu, A. Role of microRNA in endothelial dysfunction and hypertension. Curr. Hypertens. Rep. 2016, 18, 87. [CrossRef] [PubMed]

47. Manresa, N.; Mulero, J.; Losada, M.; Zafrilla, P. Influence of anti-VEGF about cardiovascular biomarkers in age related macular degeneration. J. Nutr Health Aging 2015, 19, 228-231. [CrossRef] [PubMed]

48. Du, Y.; Tu, G.; Yang, G.; Li, G.; Yang, D.; Lang, L.; Xi, L.; Sun, K.; Chen, Y.; Shu, K.; et al. MiR-205/YAP1 in activated fibroblasts of breast tumor promotes VEGF-independent angiogenesis through STAT3 signaling. Theranostics 2017, 7, 3972-3988. [CrossRef] [PubMed]

49. Espinosa-Diez, C.; Wilson, R.; Chatterjee, N.; Hudson, C.; Ruhl, R.; Hipfinger, C.; Helms, E.; Khan, O.F.; Anderson, D.G.; Anand, S. MicroRNA regulation of the MRN complex impacts DNA damage, cellular senescence, and angiogenic signaling. Cell Death Dis. 2018, 9, 632. [CrossRef] [PubMed]

50. Zhang, J.; Zhang, Z.; Zhang, D.Y.; Zhu, J.; Zhang, T.; Wang, C. microRNA 126 inhibits the transition of endothelial progenitor cells to mesenchymal cells via the PIK3R2-PI3K/Akt signalling pathway. PLoS ONE 2013, 8, e83294. [CrossRef] [PubMed] 
51. Fish, J.E.; Santoro, M.M.; Morton, S.U.; Yu, S.; Yeh, R.F.; Wythe, J.D.; Ivey, K.N.; Bruneau, B.G.; Stainier, D.Y.; Srivastava, D. miR-126 regulates angiogenic signaling and vascular integrity. Dev. Cell 2008, 15, 272-284. [CrossRef] [PubMed]

52. Wang, S.; Aurora, A.B.; Johnson, B.A.; Qi, X.; McAnally, J.; Hill, J.A.; Richardson, J.A.; Bassel-Duby, R.; Olson, E.N. The endothelial-specific microRNA miR-126 governs vascular integrity and angiogenesis. Dev. Cell 2008, 15, 261-271. [CrossRef] [PubMed]

53. Kontaraki, J.E.; Marketou, M.E.; Zacharis, E.A.; Parthenakis, F.I.; Vardas, P.E. MicroRNA-9 and microRNA-126 expression levels in patients with essential hypertension: Potential markers of target-organ damage. J. Am. Soc. Hypertens. 2014, 8, 368-375. [CrossRef] [PubMed]

54. Harris, T.A.; Yamakuchi, M.; Ferlito, M.; Mendell, J.T.; Lowenstein, C.J. MicroRNA-126 regulates endothelial expression of vascular cell adhesion molecule 1. Proc. Natl. Acad. Sci. USA 2008, 105, 1516-1521. [CrossRef] [PubMed]

55. Hua, Z.; Lv, Q.; Ye, W.; Wong, C.K.; Cai, G.; Gu, D.; Ji, Y.; Zhao, C.; Wang, J.; Yang, B.B.; et al. MiRNA-directed regulation of VEGF and other angiogenic factors under hypoxia. PLoS ONE 2006, 1, e116. [CrossRef] [PubMed]

56. Turner, N.; Grose, R. Fibroblast growth factor signalling: From development to cancer. Nat. Rev. Cancer 2010, 10, 116-129. [CrossRef] [PubMed]

57. Yang, Q.; Jia, C.; Wang, P.; Xiong, M.; Cui, J.; Li, L.; Wang, W.; Wu, Q.; Chen, Y.; Zhang, T. MicroRNA-505 identified from patients with essential hypertension impairs endothelial cell migration and tube formation. Int. J. Cardiol. 2014, 177, 925-934. [CrossRef] [PubMed]

58. Palao, T.; Swärd, K.; Jongejan, A.; Moerland, P.D.; de Vos, J.; Van Weert, A.; Arribas, S.M.; Groma, G.; Van Bavel, E.; Bakker, E.N. Gene Expression and microRNA expression analysis in small arteries of spontaneously hypertensive rats. Evidence for er stress. PLoS ONE 2015, 10, e0137027. [CrossRef] [PubMed]

59. Staszel, T.; Zapała, B.; Polus, A.; Sadakierska-Chudy, A.; Kieć-Wilk, B.; Stępień, E.; Wybrańska, I.; Chojnacka, M.; Dembińska-Kieć, A. Role of microRNAs in endothelial cell pathophysiology. Pol. Arch. Med. Wewn. 2011, 121, 361-366. [PubMed]

60. Suárez, Y.; Wang, C.; Manes, T.D.; Pober, J.S. Cutting edge: TNF-induced microRNAs regulate TNF-induced expression of E-selectin and intercellular adhesion molecule-1 on human endothelial cells: Feedback control of inflammation. J. Immunol. 2010, 184, 21-25. [CrossRef] [PubMed]

61. Pereira, C.A.; Carneiro, F.S.; Matsumoto, T.; Tostes, R.C. Bonus effects of anti-diabetic drugs: Possible beneficial effects on endothelial dysfunction, vascular inflammation and atherosclerosis. Basic Clin. Pharmacol. Toxicol. 2018, 123, 523-538. [CrossRef] [PubMed]

62. Deng, X.; Huang, W.; Peng, J.; Zhu, T.T.; Sun, X.L.; Zhou, X.Y.; Yang, H.; Xiong, J.F.; He, H.Q.; Xu, Y.H.; et al. Irisin alleviates advanced glycation end products-induced inflammation and endothelial dysfunction via inhibiting ROS-NLRP3 inflammasome signaling. Inflammation 2018, 41, 260-275. [CrossRef] [PubMed]

63. Sun, H.X.; Zeng, D.Y.; Li, R.T.; Pang, R.P.; Yang, H.; Hu, Y.L.; Zhang, Q.; Jiang, Y.; Huang, L.Y.; Tang, Y.B.; et al. Essential role of microRNA-155 in regulating endothelium-dependent vasorelaxation by targeting endothelial nitric oxide synthase. Hypertension 2012, 60, 1407-1414. [CrossRef] [PubMed]

64. Pankratz, F.; Bemtgen, X.; Zeiser, R.; Leonhardt, F.; Kreuzaler, S.; Hilgendorf, I.; Smolka, C.; Helbing, T.; Hoefer, I.; Esser, J.S.; et al. MicroRNA-155 exerts cell-specific antiangiogenic but proarteriogenic effects during adaptive neovascularization. Circulation 2015, 131, 1575-1589. [CrossRef] [PubMed]

65. Qin, X.; Wang, X.; Wang, Y.; Tang, Z.; Cui, Q.; Xi, J.; Li, Y.S.; Chien, S.; Wang, N. MicroRNA-19a mediates the suppressive effect of laminar flow on cyclin D1 expression in human umbilical vein endothelial cells. Proc. Natl. Acad. Sci. USA 2010, 107, 3240-3244. [CrossRef] [PubMed]

66. Tang, Y.; Zhang, Y.C.; Chen, Y.; Xiang, Y.; Shen, C.X.; Li, Y.G. The role of miR-19b in the inhibition of endothelial cell apoptosis and its relationship with coronary artery disease. Sci. Rep. 2015, 5, 15132. [CrossRef] [PubMed]

67. Zhang, Y.; Chen, N.; Zhang, J.; Tong, Y. Hsa-let-7g miRNA targets caspase-3 and inhibits the apoptosis induced by ox-LDL in endothelial cells. Int. J. Mol. Sci. 2013, 14, 22708-22720. [CrossRef] [PubMed]

68. White, K.; Dempsie, Y.; Caruso, P.; Wallace, E.; McDonald, R.A.; Stevens, H.; Hatley, M.E.; Van Rooij, E.; Morrell, N.W.; MacLean, M.R.; et al. Endothelial apoptosis in pulmonary hypertension is controlled by a microRNA/programmed cell death 4/caspase-3 axis. Hypertension 2014, 64, 185-194. [CrossRef] [PubMed] 
69. Pan, Y.; Liang, H.; Liu, H.; Li, D.; Chen, X.; Li, L.; Zhang, C.Y.; Zen, K. Platelet-secreted microRNA-223 promotes endothelial cell apoptosis induced by advanced glycation end products via targeting the insulin-like growth factor 1 receptor. J. Immunol. 2014, 192, 437-446. [CrossRef] [PubMed]

70. Dickinson, B.A.; Semus, H.M.; Montgomery, R.L.; Stack, C.; Latimer, P.A.; Lewton, S.M.; Lynch, J.M.; Hullinger, T.G.; Seto, A.G.; Van Rooij, E. Plasma microRNAs serve as biomarkers of therapeutic efficacy and disease progression in hypertension-induced heart failure. Eur. J. Heart Fail. 2013, 15, 650-659. [CrossRef] [PubMed]

71. Wu, W.H.; Hu, C.P.; Chen, X.P.; Zhang, W.F.; Li, X.W.; Xiong, X.M.; Li, Y.J. MicroRNA-130a mediates proliferation of vascular smooth muscle cells in hypertension. Am. J. Hypertens. 2011, 24, 1087-1093. [CrossRef] [PubMed]

72. Davis, B.N.; Hilyard, A.C.; Nguyen, P.H.; Lagna, G.; Hata, A. Induction of microRNA-221 by platelet-derived growth factor signaling is critical for modulation of vascular smooth muscle phenotype. J. Biol. Chem. 2009, 284, 3728-3738. [CrossRef] [PubMed]

73. Mandraffino, G.; Imbalzano, E.; Sardo, M.A.; D'Ascola, A.; Mamone, F.; Lo Gullo, A.; Alibrandi, A.; Loddo, S.; Mormina, E.; David, A.; et al. Circulating progenitor cells in hypertensive patients with different degrees of cardiovascular involvement. J. Hum. Hypertens. 2014, 28, 543-550. [CrossRef] [PubMed]

74. Carr, G.; Barrese, V.; Stott, J.B.; Povstyan, O.V.; Jepps, T.A.; Figueiredo, H.B.; Zheng, D.; Jamshidi, Y.; Greenwood, I.A. MicroRNA-153 targeting of KCNQ4 contributes to vascular dysfunction in hypertension. Cardiovasc. Res. 2016, 112, 581-589. [CrossRef] [PubMed]

75. Kontaraki, J.E.; Marketou, M.E.; Zacharis, E.A.; Parthenakis, F.I.; Vardas, P.E. Differential expression of vascular smooth muscle-modulating microRNAs in human peripheral blood mononuclear cells: Novel targets in essential hypertension. J. Hum. Hypertens. 2014, 28, 510-516. [CrossRef] [PubMed]

76. Elia, L.; Quintavalle, M.; Zhang, J.; Contu, R.; Cossu, L.; Latronico, M.V.; Peterson, K.L.; Indolfi, C.; Catalucci, D.; Chen, J.; et al. The knockout of miR-143 and -145 alters smooth muscle cell maintenance and vascular homeostasis in mice: Correlates with human disease. Cell Death Differ. 2009, 16, 1590-1598. [CrossRef] [PubMed]

77. Torella, D.; Iaconetti, C.; Catalucci, D.; Ellison, G.M.; Leone, A.; Waring, C.D.; Bochicchio, A.; Vicinanza, C.; Aquila, I.; Curcio, A.; et al. MicroRNA-133 controls vascular smooth muscle cell phenotypic switch in vitro and vascular remodeling in vivo. Circ. Res. 2011, 109, 880-893. [CrossRef] [PubMed]

78. Zhang, P.; Zheng, C.; Ye, H.; Teng, Y.; Zheng, B.; Yang, X.; Zhang, J. MicroRNA-365 inhibits vascular smooth muscle cell proliferation through targeting cyclin D1. Int. J. Med. Sci. 2014, 11, 765-770. [CrossRef] [PubMed]

79. Kim, M.H.; Ham, O.; Lee, S.Y.; Choi, E.; Lee, C.Y.; Park, J.H.; Lee, J.; Seo, H.H.; Seung, M.; Min, P.K.; et al. MicroRNA-365 inhibits the proliferation of vascular smooth muscle cells by targeting cyclin D1. J. Cell Biochem. 2014, 115, 1752-1761. [CrossRef] [PubMed]

80. Leeper, N.J.; Raiesdana, A.; Kojima, Y.; Chun, H.J.; Azuma, J.; Maegdefessel, L.; Kundu, R.K.; Quertermous, T.; Tsao, P.S.; Spin, J.M. MicroRNA-26a is a novel regulator of vascular smooth muscle cell function. J. Cell Physiol. 2011, 226, 1035-1043. [CrossRef] [PubMed]

81. Yang, F.; Li, H.; Du, Y.; Shi, Q.; Zhao, L. Downregulation of microRNA-34b is responsible for the elevation of blood pressure in spontaneously hypertensive rats. Mol. Med. Rep. 2017, 15, 1031-1036. [CrossRef] [PubMed]

82. Pacurari, M.; Tchounwou, P.B. Role of microRNAs in renin-angiotensin-aldosterone system-mediated cardiovascular inflammation and remodeling. Int. J. Inflamm. 2015, 2015, 101527. [CrossRef] [PubMed]

83. Takahashi, Y.; Satoh, M.; Minami, Y.; Tabuchi, T.; Itoh, T.; Nakamura, M. Expression of miR-146a/b is associated with the Toll-like receptor 4 signal in coronary artery disease: Effect of renin-angiotensin system blockade and statins on miRNA-146a/b and Toll-like receptor 4 levels. Clin. Sci. 2010, 119, 395-405. [CrossRef] [PubMed]

84. Jeunemaitre, X. Genetics of the human renin angiotensin system. J. Mol. Med. 2008, 86, 637-641. [CrossRef] [PubMed]

85. Chen, L.J.; Xu, R.; Yu, H.M.; Chang, Q.; Zhong, J.C. The ACE2/apelin signaling, microRNAs, and hypertension. Int. J. Hypertens. 2015, 2015, 896861. [CrossRef] [PubMed]

86. Kemp, J.R.; Unal, H.; Desnoyer, R.; Yue, H.; Bhatnagar, A.; Karnik, S.S. Angiotensin II-regulated microRNA 483-3p directly targets multiple components of the renin-angiotensin system. J. Mol. Cell. Cardiol. 2014, 75, 25-39. [CrossRef] [PubMed] 
87. Ceolotto, G.; Papparella, I.; Bortoluzzi, A.; Strapazzon, G.; Ragazzo, F.; Bratti, P.; Fabricio, A.S.; Squarcina, E.; Gion, M.; Palatini, P.; et al. Interplay between miR-155, AT1R A1166C polymorphism, and AT1R expression in young untreated hypertensives. Am. J. Hypertens. 2011, 24, 241-246. [CrossRef] [PubMed]

88. Nossent, A.Y.; Eskildsen, T.V.; Andersen, L.B.; Bie, P.; Brønnum, H.; Schneider, M.; Andersen, D.C.; Welten, S.M.; Jeppesen, P.L.; Hamming, J.F.; et al. The $14 \mathrm{q} 32$ microRNA-487b targets the antiapoptotic insulin receptor substrate 1 in hypertension-induced remodeling of the aorta. Ann. Surg. 2013, 258, 743-753. [CrossRef] [PubMed]

89. Jackson, K.L.; Marques, F.Z.; Watson, A.M.; Palma-Rigo, K.; Nguyen-Huu, T.P.; Morris, B.J.; Charchar, F.J.; Davern, P.J.; Head, G.A. A novel interaction between sympathetic overactivity and aberrant regulation of renin by miR-181a in BPH/2J genetically hypertensive mice. Hypertension 2013, 62, 775-781. [CrossRef] [PubMed]

90. Marques, F.Z.; Campain, A.E.; Tomaszewski, M.; Zukowska-Szczechowska, E.; Yang, Y.H.J.; Charchar, F.J.; Morris, B.J. Gene expression profiling reveals renin mRNA overexpression in human hypertensive kidneys and a role for microRNAs. Hypertension 2011, 58, 1093-1098. [CrossRef] [PubMed]

91. Marques, F.Z.; Romaine, S.P.R.; Denniff, M.; Eales, J.; Dormer, J.; Garrelds, I.M.; Wojnar, L.; Musialik, K.; Duda-Raszewska, B.; Kiszka, B.; et al. Signatures of miR-181a on renal transcriptome and blood pressure. Mol. Med. 2015, 21, 739-748. [CrossRef] [PubMed]

92. Winklewski, P.J.; Radkowski, M.; Wszedybyl-Winklewska, M.; Demkow, U. Brain inflammation and hypertension: The chicken or the egg? J. Neuroinflamm. 2015, 12, 85. [CrossRef] [PubMed]

93. Sivasinprasasn, S.; Pantan, R.; Thummayot, S.; Tocharus, J.; Suksamrarn, A.; Tocharus, C. Cyanidin-3-glucoside attenuates angiotensin II-induced oxidative stress and inflammation in vascular endothelial cells. Chem. Biol. Interact. 2016, 260, 67-74. [CrossRef] [PubMed]

94. DeCicco, D.; Zhu, H.; Brureau, A.; Schwaber, J.S.; Vadigepalli, R. MicroRNA network changes in the brain stem underlie the development of hypertension. Physiol. Genomics 2015, 47, 388-399. [CrossRef] [PubMed]

95. Friese, R.S.; Altshuler, A.E.; Zhang, K.; Miramontes-Gonzalez, J.P.; Hightower, C.M.; Jirout, M.L.; Salem, R.M.; Gayen, J.R.; Mahapatra, N.R.; Biswas, N.; et al. MicroRNA-22 and promoter motif polymorphisms at the Chga locus in genetic hypertension: Functional and therapeutic implications for gene expression and the pathogenesis of hypertension. Hum. Mol. Genet. 2013, 22, 3624-3640. [CrossRef] [PubMed]

96. Huang, Y.; Tang, S.; Ji-yan, C.; Huang, C.; Li, J.; Cai, A.; Feng, Y. Circulating miR-92a expression level in patients with essential hypertension: A potential marker of atherosclerosis. J. Hum. Hypertens. 2017, 31, 200-205. [CrossRef] [PubMed]

97. Huang, Y.; Tang, S.; Huang, C.; Chen, J.; Li, J.; Cai, A.; Feng, Y. Circulating miRNA29 family expression levels in patients with essential hypertension as potential markers for left ventricular hypertrophy. Clin. Exp. Hypertens. 2017, 39, 119-125. [CrossRef] [PubMed]

98. Kontaraki, J.E.; Marketou, M.E.; Parthenakis, F.I.; Maragkoudakis, S.; Zacharis, E.A.; Petousis, S.; Kochiadakis, G.E.; Vardas, P.E. Hypertrophic and antihypertrophic microRNA levels in peripheral blood mononuclear cells and their relationship to left ventricular hypertrophy in patients with essential hypertension. J. Am. Soc. Hypertens. 2015, 9, 802-810. [CrossRef] [PubMed]

99. Li, S.; Zhu, J.; Zhang, W.; Chen, Y.; Zhang, K.; Popescu, L.M.; Ma, X.; Bond Lau, W.; Rong, R.; Yu, X.; et al. Signature microRNA expression profile of essential hypertension and its novel link to human cytomegalovirus infection. Circulation 2011, 124, 175-184. [CrossRef] [PubMed]

100. Yi, F.; Hao, Y.; Chong, X.; Zhong, W. Overexpression of microRNA-506-3p aggravates the injury of vascular endothelial cells in patients with hypertension by downregulating Beclin1 expression. Exp. Ther. Med. 2018, 15, 2844-2850. [CrossRef] [PubMed]

101. Yang, Z.; Venardos, K.; Jones, E.; Morris, B.J.; Chin-Dusting, J.; Kaye, D.M. Identification of a novel polymorphism in the 3'UTR of the L-arginine transporter gene SLC7A1: Contribution to hypertension and endothelial dysfunction. Circulation 2007, 115, 1269-1274. [CrossRef] [PubMed]

102. Arora, P.; Wu, C.; Khan, A.M.; Bloch, D.B.; Davis-Dusenbery, B.N.; Ghorbani, A.; Spagnolli, E.; Martinez, A.; Ryan, A.; Tainsh, L.T.; et al. Atrial natriuretic peptide is negatively regulated by microRNA-425. J. Clin. Investig. 2013, 123, 3378-3382. [CrossRef] [PubMed]

103. Maharjan, S.; Mopidevi, B.; Kaw, M.K.; Puri, N.; Kumar, A. Human aldosterone synthase gene polymorphism promotes miRNA binding and regulates gene expression. Physiol. Genomics 2014, 46, 860-865. [CrossRef] [PubMed] 
104. Korkor, M.T.; Meng, F.B.; Xing, S.Y.; Zhang, M.C.; Guo, J.R.; Zhu, X.X.; Yang, P. Microarray analysis of differential gene expression profile in peripheral blood cells of patients with human essential hypertension. Int. J. Med. Sci. 2011, 8, 168-179. [CrossRef] [PubMed]

105. Whiting, D.R.; Guariguata, L.; Weil, C.; Shaw, J. IDF diabetes atlas: Global estimates of the prevalence of diabetes for 2011 and 2030. Diabetes Res. Clin. Pract. 2011, 94, 311-321. [CrossRef] [PubMed]

106. Prentki, M.; Nolan, C.J. Islet cell failure in type 2 diabetes. J. Clin. Investig. 2006, 116, 1802-1812. [CrossRef] [PubMed]

107. Stępień, E.; Stankiewicz, E.; Zalewski, J.; Godlewski, J.; Zmudka, K.; Wybrańska, I. Number of microparticles generated during acute myocardial infarction and stable angina correlates with platelet activation. Arch. Med. Res. 2012, 43, 31-35. [CrossRef] [PubMed]

108. Stępień, E.L.; Durak-Kozica, M.; Kamińska, A.; Targosz-Korecka, M.; Libera, M.; Tylko, G.; Opalińska, A.; Kapusta, M.; Solnica, B.; Georgescu, A.; et al. Circulating ectosomes: Determination of angiogenic microRNAs in type 2 diabetes. Theranostics 2018, 8, 3874-3890. [CrossRef] [PubMed]

109. Shantikumar, S.; Caporali, A.; Emanueli, C. Role of microRNAs in diabetes and its cardiovascular complications. Cardiovasc. Res. 2012, 93, 583-593. [CrossRef] [PubMed]

110. Murach, K.A.; McCarthy, J.J. MicroRNAs, heart failure, and aging: Potential interactions with skeletal muscle. Heart Fail. Rev. 2017, 22, 209-218. [CrossRef] [PubMed]

111. Drummond, M.J.; McCarthy, J.J.; Fry, C.S.; Esser, K.A.; Rasmussen, B.B. Aging differentially affects human skeletal muscle microRNA expression at rest and after an anabolic stimulus of resistance exercise and essential amino acids. Am. J. Physiol. Endocrinol. Metab. 2008, 295, E1333-E1340. [CrossRef] [PubMed]

112. Poy, M.N.; Eliasson, L.; Krutzfeldt, J.; Kuwajima, S.; Ma, X.; Macdonald, P.E.; Pfeffer, S.; Tuschl, T.; Rajewsky, N.; Rorsman, P.; et al. A pancreatic islet-specific microRNA regulates insulin secretion. Nature 2004, 432, 226-230. [CrossRef] [PubMed]

113. Baroukh, N.; Ravier, M.A.; Loder, M.K.; Hill, E.V.; Bounacer, A.; Scharfmann, R.; Rutter, G.A.; Van Obberghen, E. MicroRNA-124a regulates Foxa2 expression and intracellular signaling in pancreatic $\beta$-cell lines. J. Biol. Chem. 2007, 282, 19575-19588. [CrossRef] [PubMed]

114. Lovis, P.; Gattesco, S.; Regazzi, R. Regulation of the expression of components of the exocytotic machinery of insulin-secreting cells by microRNAs. Biol. Chem. 2008, 389, 305-312. [CrossRef] [PubMed]

115. Tang, X.; Muniappan, L.; Tang, G.; Ozcan, S. Identification of glucose-regulated miRNAs from pancreatic $\{\beta\}$ cells reveals a role for miR-30d in insulin transcription. RNA 2009, 15, 287-293. [CrossRef] [PubMed]

116. Ortega, F.J.; Moreno-Navarrete, J.M.; Pardo, G.; Sabater, M.; Hummel, M.; Ferrer, A.; Rodriguez-Hermosa, J.I.; Ruiz, B.; Ricart, W.; Peral, B.; et al. MiRNA expression profile of human subcutaneous adipose and during adipocyte differentiation. PLoS ONE 2010, 5, e9022. [CrossRef] [PubMed]

117. Barbagallo, D.; Piro, S.; Condorelli, A.G.; Mascali, L.G.; Urbano, F.; Parrinello, N.; Monello, A.; Statello, L.; Ragusa, M.; Rabuazzo, A.M.; et al. miR-296-3p, miR-298-5p and their downstream networks are causally involved in the higher resistance of mammalian pancreatic $\alpha$ cells to cytokine-induced apoptosis as compared to $\beta$ cells. BMC Genomics 2013, 14, 62. [CrossRef] [PubMed]

118. Joglekar, M.V.; Joglekar, V.M.; Hardikar, A.A. Expression of islet-specific microRNAs during human pancreatic development. Gene Expr. Patterns 2009, 9, 109-113. [CrossRef] [PubMed]

119. El Ouaamari, A.; Baroukh, N.; Martens, G.A.; Lebrun, P.; Pipeleers, D.; Van Obberghen, E. miR-375 targets 3 '-phosphoinositide-dependent protein kinase-1 and regulates glucose-induced biological responses in pancreatic $\beta$-cells. Diabetes 2008, 57, 2708-2717. [CrossRef] [PubMed]

120. Kong, L.; Zhu, J.; Han, W.; Jiang, X.; Xu, M.; Zhao, Y.; Dong, Q.; Pang, Z.; Guan, Q.; Gao, L.; et al. Significance of serum microRNAs in pre-diabetes and newly diagnosed type 2 diabetes: A clinical study. Acta Diabetol. 2011, 48, 61-69. [CrossRef] [PubMed]

121. Higuchi, C.; Nakatsuka, A.; Eguchi, J.; Teshigawara, S.; Kanzaki, M.; Katayama, A.; Yamaguchi, S.; Takahashi, N.; Murakami, K.; Ogawa, D.; et al. Identification of circulating miR-101, miR-375 and miR-802 as biomarkers for type 2 diabetes. Metabolism 2015, 64, 489-497. [CrossRef] [PubMed]

122. Plaisance, V.; Abderrahmani, A.; Perret-Menoud, V.; Jacquemin, P.; Lemaigre, F.; Regazzi, R. MicroRNA-9 controls the expression of Granuphilin/Slp4 and the secretory response of insulin-producing cells. J. Biol. Chem. 2006, 281, 26932-26942. [CrossRef] [PubMed] 
123. Herrera, B.M.; Lockstone, H.E.; Taylor, J.M.; Ria, M.; Barrett, A.; Collins, S.; Kaisaki, P.; Argoud, K.; Fernandez, C.; Travers, M.E.; et al. Global microRNA expression profiles in insulin target tissues in a spontaneous rat model of type 2 diabetes. Diabetologia 2010, 53, 1099-1109. [CrossRef] [PubMed]

124. Kim, J.A.; Wei, Y.; Sowers, J.R. Role of mitochondrial dysfunction in insulin resistance. Circ. Res. 2008, 102, 401-414. [CrossRef] [PubMed]

125. Prabu, P.; Rome, S.; Sathishkumar, C.; Aravind, S.; Mahalingam, B.; Shanthirani, C.S.; Gastebois, C.; Villard, A.; Mohan, V.; Balasubramanyam, M. Circulating miRNAs of "asian indian phenotype" identified in subjects with impaired glucose tolerance and patients with type 2 diabetes. PLOS ONE 2015, 10, e0128372. [CrossRef] [PubMed]

126. Motohashi, N.; Alexander, M.S.; Shimizu-Motohashi, Y.; Myers, J.A.; Kawahara, G.; Kunkel, L.M. Regulation of IRS1/Akt insulin signaling by microRNA-128a during myogenesis. J. Cell Sci. 2013, 126, 2678-2691. [CrossRef] [PubMed]

127. Karolina, D.S.; Armugam, A.; Tavintharan, S.; Wong, M.T.; Lim, S.C.; Sum, C.F.; Jeyaseelan, K. MicroRNA 144 impairs insulin signaling by inhibiting the expression of insulin receptor substrate 1 in type 2 diabetes mellitus. PLoS ONE 2011, 6, e22839. [CrossRef]

128. Yang, Z.M.; Chen, L.H.; Hong, M.; Chen, Y.Y.; Yang, X.R.; Tang, S.M.; Yuan, Q.F.; Chen, W.W. Serum microRNA profiling and bioinformatics analysis of patients with type 2 diabetes mellitus in a Chinese population. Mol. Med. Rep. 2017, 15, 2143-2153. [CrossRef] [PubMed]

129. Ryu, H.S.; Park, S.Y.; Ma, D.; Zhang, J.; Lee, W. The induction of microRNA targeting IRS-1 is involved in the development of insulin resistance under conditions of mitochondrial dysfunction in hepatocytes. PLoS ONE 2011, 6, e17343. [CrossRef]

130. Fernandez-Twinn, D.S.; Alfaradhi, M.Z.; Martin-Gronert, M.S.; Duque-Guimaraes, D.E.; Piekarz, A.; Ferland-McCollough, D.; Bushell, M.; Ozanne, S.E. Downregulation of IRS-1 in adipose tissue of offspring of obese mice is programmed cell-autonomously through post-transcriptional mechanisms. Mol. Metab. 2014, 3, 325-333. [CrossRef] [PubMed]

131. He, J.; Li, Y.; Yang, X.; He, X.; Zhang, H.; Zhang, L. The feedback regulation of PI3K-miR-19a, and MAPK-miR-23b/27b in endothelial cells under shear stress. Molecules 2012, 18, 1-13. [CrossRef] [PubMed]

132. Park, S.Y.; Lee, J.H.; Ha, M.; Nam, J.W.; Kim, V.N. miR-29 miRNAs activate p53 by targeting p $85 \alpha$ and CDC42. Nat. Struct. Mol. Biol. 2009, 16, 23-29. [CrossRef] [PubMed]

133. Bao, Y.; Lin, C.; Ren, J.; Liu, J. MicroRNA-384-5p regulates ischemia-induced cardioprotection by targeting phosphatidylinositol-4,5-bisphosphate 3-kinase, catalytic subunit delta (PI3K p1108). Apoptosis 2013, 18, 260-270. [CrossRef] [PubMed]

134. He, A.; Zhu, L.; Gupta, N.; Chang, Y.; Fang, F. Overexpression of Micro Ribonucleic Acid 29, Highly Up-Regulated in Diabetic Rats, Leads to Insulin Resistance in 3T3-L1 Adipocytes. Mol. Endocrinol. 2007, 21, 2785-2794. [CrossRef] [PubMed]

135. Dooley, J.; Garcia-Perez, J.E.; Sreenivasan, J.; Schlenner, S.M.; Vangoitsenhoven, R.; Papadopoulou, A.S.; Tian, L.; Schonefeldt, S.; Serneels, L.; Deroose, C.; et al. The microRNA-29 family dictates the balance between homeostatic and pathological glucose handling in diabetes and obesity. Diabetes 2016, 65, 53-61. [CrossRef] [PubMed]

136. Vatandoost, N.; Amini, M.; Iraj, B.; Momenzadeh, S.; Salehi, R. Dysregulated miR-103 and miR-143 expression in peripheral blood mononuclear cells from induced prediabetes and type 2 diabetes rats. Gene 2015, 572, 95-100. [CrossRef] [PubMed]

137. Gray, S.; Feinberg, M.W.; Hull, S.; Kuo, C.T.; Watanabe, M.; Banerjee, S.S.; DePina, A.; Haspel, R.; Jain, M.K. The Krüppel-like Factor KLF15 Regulates the Insulin-sensitive Glucose Transporter GLUT4. J. Biol. Chem. 2002, 277, 34322-34328. [CrossRef] [PubMed]

138. Horie, T.; Ono, K.; Nishi, H.; Iwanaga, Y.; Nagao, K.; Kinoshita, M.; Kuwabara, Y.; Takanabe, R.; Hasegawa, K.; Kita, T; et al. MicroRNA-133 regulates the expression of GLUT4 by targeting KLF15 and is involved in metabolic control in cardiac myocytes. Biochem. Biophys. Res. Commun. 2009, 389, 315-320. [CrossRef] [PubMed]

139. Ling, H.Y.; Hu, B.; Hu, X.B.; Zhong, J.; Feng, S.D.; Qin, L.; Liu, G.; Wen, G.B.; Liao, D.F. MiRNA-21 reverses high glucose and high insulin induced insulin resistance in 3T3-L1 adipocytes through targeting phosphatase and tensin homologue. Exp. Clin. Endocrinol. Diabetes 2012, 120, 553-559. [CrossRef] [PubMed] 
140. Lu, H.; Buchan, R.J.; Cook, S.A. MicroRNA-223 regulates Glut4 expression and cardiomyocyte glucose metabolism. Cardiovasc. Res. 2010, 86, 410-420. [CrossRef] [PubMed]

141. Zhou, T.; Meng, X.; Che, H.; Shen, N.; Xiao, D.; Song, X.; Liang, M.; Fu, X.; Ju, J.; Li, Y.; et al. Regulation of insulin resistance by multiple miRNAs via targeting the GLUT4 signalling pathway. Cell. Physiol. Biochem. 2016, 38, 2063-2078. [CrossRef] [PubMed]

142. Liu, Y.; Gao, G.; Yang, C.; Zhou, K.; Shen, B.; Liang, H.; Jiang, X. The role of circulating microRNA-126 (miR-126): A novel biomarker for screening prediabetes and newly diagnosed type 2 diabetes mellitus. Int. J. Mol. Sci. 2014, 15, 10567-10577. [CrossRef] [PubMed]

143. Zhang, T.; Li, L.; Shang, Q.; Lv, C.; Wang, C.; Su, B. Circulating miR-126 is a potential biomarker to predict the onset of type 2 diabetes mellitus in susceptible individuals. Biochem. Biophys. Res. Commun. 2015, 463, 60-63. [CrossRef] [PubMed]

144. Zampetaki, A.; Kiechl, S.; Drozdov, I.; Willeit, P.; Mayr, U.; Prokopi, M.; Mayr, A.; Weger, S.; Oberhollenzer, F.; Bonora, E.; et al. Plasma microRNA profiling reveals loss of endothelial miR-126 and other microRNAs in type 2 diabetes. Circ. Res. 2010, 107, 810-817. [CrossRef] [PubMed]

145. Olivieri, F.; Spazzafumo, L.; Bonafè, M.; Recchioni, R.; Prattichizzo, F.; Marcheselli, F.; Micolucci, L.; Mensà, E.; Giuliani, A.; Santini, G.; et al. MiR-21-5p and miR-126a-3p levels in plasma and circulating angiogenic cells: Relationship with type 2 diabetes complications. Oncotarget 2015, 6, 35372-35382. [CrossRef] [PubMed]

146. Ortega, F.J.; Mercader, J.M.; Moreno-Navarrete, J.M.; Rovira, O.; Guerra, E.; Esteve, E.; Xifra, G.; Martínez, C.; Ricart, W.; Rieusset, J.; et al. Profiling of circulating microRNAs reveals common microRNAs linked to type 2 diabetes that change with insulin sensitization. Diabetes Care 2014, 37, 1375-1383. [CrossRef] [PubMed]

147. Meng, S.; Cao, J.T.; Zhang, B.; Zhou, Q.; Shen, C.X.; Wang, C.Q. Downregulation of microRNA-126 in endothelial progenitor cells from diabetes patients, impairs their functional properties, via target gene Spred-1. J. Mol. Cell. Cardiol. 2012, 53, 64-72. [CrossRef] [PubMed]

148. Esau, C.; Davis, S.; Murray, S.F.; Yu, X.X.; Pandey, S.K.; Pear, M.; Watts, L.; Booten, S.L.; Graham, M.; McKay, R.; et al. miR-122 regulation of lipid metabolism revealed by in vivo antisense targeting. Cell Metab. 2006, 3, 87-98. [CrossRef] [PubMed]

149. Iliopoulos, D.; Drosatos, K.; Hiyama, Y.; Goldberg, I.J.; Zannis, V.I. MicroRNA-370 controls the expression of microRNA-122 and Cpt1alpha and affects lipid metabolism. J. Lipid Res. 2010, 51, 1513-1523. [CrossRef] [PubMed]

150. Xu, P.; Vernooy, S.Y.; Guo, M.; Hay, B.A. The Drosophila microRNA Mir-14 suppresses cell death and is required for normal fat metabolism. Curr. Biol. 2003, 13, 790-795. [CrossRef]

151. Gerin, I.; Bommer, G.T.; McCoin, C.S.; Sousa, K.M.; Krishnan, V.; MacDougald, O.A. Roles for miRNA-378/378* in adipocyte gene expression and lipogenesis. Am. J. Physiol. Endocrinol. Metab. 2010, 299, E198-E206. [CrossRef] [PubMed]

152. Rayner, K.J.; Suárez, Y.; Dávalos, A.; Parathath, S.; Fitzgerald, M.L.; Tamehiro, N.; Fisher, E.A.; Moore, K.J.; Fernández-Hernando, C. MiR-33 contributes to the regulation of cholesterol homeostasis. Science 2010, 328, 1570-1573. [CrossRef] [PubMed]

153. Najafi-Shoushtari, S.H.; Kristo, F.; Li, Y.; Shioda, T.; Cohen, D.E.; Gerszten, R.E.; Näär, A.M. MicroRNA-33 and the SREBP host genes cooperate to control cholesterol homeostasis. Science 2010, 328, 1566-1569. [CrossRef] [PubMed]

154. Cao, Y.; Jiang, X.; Ma, H.; Wang, Y.; Xue, P.; Liu, Y. SIRT1 and insulin resistance. J. Diabetes Complicat. 2016, 30, 178-183. [CrossRef] [PubMed]

155. Zhou, B.; Li, C.; Qi, W.; Zhang, Y.; Zhang, F.; Wu, J.X.; Hu, Y.N.; Wu, D.M.; Liu, Y.; Yan, T.T.; et al. Downregulation of miR-181a upregulates sirtuin-1 (SIRT1) and improves hepatic insulin sensitivity. Diabetologia 2012, 55, 2032-2043. [CrossRef] [PubMed]

156. Raut, S.K.; Singh, G.B.; Rastogi, B.; Saikia, U.N.; Mittal, A.; Dogra, N.; Singh, S.; Prasad, R.; Khullar, M. $\mathrm{miR}-30 \mathrm{c}$ and miR-181a synergistically modulate p53-p21 pathway in diabetes induced cardiac hypertrophy. Mol. Cell. Biochem. 2016, 417, 191-203. [CrossRef] [PubMed]

157. Jiao, Y.; Zhu, M.; Mao, X.; Long, M.; Du, X.; Wu, Y.; Abudureyimu, K.; Zhang, C.; Wang, Y.; Tao, Y.; et al. MicroRNA-130a expression is decreased in Xinjiang Uygur patients with type 2 diabetes mellitus. Am. J. Transl. Res. 2015, 7, 1984-1991. [PubMed] 
158. Yan, S.; Wang, T.; Huang, S.; Di, Y.; Huang, Y.; Liu, X.; Luo, Z.; Han, W.; An, B. Differential expression of microRNAs in plasma of patients with prediabetes and newly diagnosed type 2 diabetes. Acta Diabetol. 2016, 53, 693-702. [CrossRef] [PubMed]

159. Pescador, N.; Pérez-Barba, M.; Ibarra, J.M.; Corbatón, A.; Martínez-Larrad, M.T.; Serrano-Ríos, M. Serum circulating microRNA profiling for identification of potential type 2 diabetes and obesity biomarkers. PLOS ONE 2013, 8, e77251. [CrossRef] [PubMed]

160. Yang, Z.; Chen, H.; Si, H.; Li, X.; Ding, X.; Sheng, Q.; Chen, P.; Zhang, H. Serum miR-23a, a potential biomarker for diagnosis of pre-diabetes and type 2 diabetes. Acta Diabetol. 2014, 51, 823-831. [CrossRef] [PubMed]

161. Frayling, T.M. Genome-wide association studies provide new insights into type 2 diabetes aetiology. Nat. Rev. Genet. 2007, 8, 657-662. [CrossRef] [PubMed]

162. McCarthy, M.I. Genomics, type 2 diabetes, and obesity. N. Engl. J. Med. 2010, 363, 2339-2350. [CrossRef] [PubMed]

163. Tong, Y.; Lin, Y.; Zhang, Y.; Yang, J.; Zhang, Y.; Liu, H.; Zhang, B. Association between TCF7L2 gene polymorphisms and susceptibility to type 2 diabetes mellitus: A large Human Genome Epidemiology (HuGE) review and meta-analysis. BMC Med. Genet. 2009, 10, 15. [CrossRef] [PubMed]

164. Jurado, J.; Ybarra, J.; Romeo, J.H.; Garcia, M.; Zabaleta-Del-Olmo, E. Angiotensin-converting enzyme gene single polymorphism as a genetic biomarker of diabetic peripheral neuropathy: Longitudinal prospective study. J. Diabetes Complicat. 2012, 26, 77-82. [CrossRef] [PubMed]

165. Ji, Z.Y.; Li, H.F.; Lei, Y.; Rao, Y.W.; Tan, Z.X.; Liu, H.J.; Yao, G.D.; Hou, B.; Sun, M.L. Association of adiponectin gene polymorphisms with an elevated risk of diabetic peripheral neuropathy in type 2 diabetes patients. J. Diabetes Complicat. 2015, 29, 887-892. [CrossRef] [PubMed]

166. Chanprasertyothin, S.; Jongjaroenprasert, W.; Ongphiphadhanakul, B. The association of soluble IGF2R and IGF2R gene polymorphism with type 2 diabetes. J. Diabetes Res. 2015, 2015, 216383. [CrossRef] [PubMed]

167. Ali, S.; Nafis, S.; Kalaiarasan, P.; Rai, E.; Sharma, S.; Bamezai, R.N. Understanding genetic heterogeneity in type 2 diabetes by delineating physiological phenotypes: SIRT1 and its gene network in impaired insulin secretion. Rev. Diabet. Stud. 2016, 13, 17-34. [CrossRef] [PubMed]

168. Holt, R.I.G.; Simpson, H.L.; Sönksen, P.H. The role of the growth hormone-insulin-like growth factor axis in glucose homeostasis. Diabet. Med. 2003, 20, 3-15. [CrossRef] [PubMed]

169. Ong, K.K.; Dunger, D.B. Developmental aspects in the pathogenesis of type 2 diabetes. Mol. Cell. Endocrinol. 2001, 185, 145-149. [CrossRef]

170. McCann, J.A.; Xu, Y.Q.; Frechette, R.; Guazzarotti, L.; Polychronakos, C. The insulin-like growth factor-II receptor gene is associated with type 1 diabetes: Evidence of a maternal effect. J. Clin. Endocrinol. Metab. 2004, 89, 5700-5706. [CrossRef] [PubMed]

171. Villuendas, G.; Botella-Carretero, J.I.; López-Bermejo, A.; Gubern, C.; Ricart, W.; Fernández-Real, J.M.; San Millán, J.L.; Escobar-Morreale, H.F. The ACAA-insertion/deletion polymorphism at the 3' UTR of the IGF-II receptor gene is associated with type 2 diabetes and surrogate markers of insulin resistance. Eur. J. Endocrinol. 2006, 155, 331-336. [CrossRef] [PubMed]

172. Lv, K.; Guo, Y.; Zhang, Y.; Wang, K.; Jia, Y.; Sun, S. Allele-specific targeting of hsa-miR-657 to human IGF2R creates a potential mechanism underlying the association of ACAA-insertion/deletion polymorphism with type 2 diabetes. Biochem. Biophys. Res. Commun. 2008, 374, 101-105. [CrossRef] [PubMed]

173. Hatefi, Z.; Soltani, G.; Khosravi, S.; Kazemi, M.; Salehi, A.R.; Salehi, R. Micro R-410 binding site single nucleotide polymorphism rs13702 in lipoprotein lipase gene is effective to increase susceptibility to type 2 diabetes in iranian population. Adv. Biomed. Res. 2018, 7, 79. [CrossRef] [PubMed]

174. Lovis, P.; Roggli, E.; Laybutt, D.R.; Gattesco, S.; Yang, J.Y.; Widmann, C.; Abderrahmani, A.; Regazzi, R. Alterations in microRNA expression contribute to fatty acid-induced pancreatic beta-cell dysfunction. Diabetes 2008, 57, 2728-2736. [CrossRef] [PubMed]

175. Frost, R.J.A.; Olson, E.N. Control of glucose homeostasis and insulin sensitivity by the Let-7 family of microRNAs. Proc. Natl. Acad. Sci. USA 2011, 108, 21075-21080. [CrossRef] [PubMed]

176. Zhou, J.; Peng, R.; Li, T.; Luo, X.; Peng, H.; Zha, H.; Yin, P.; Wen, L.; Zhang, Z. A potentially functional polymorphism in the regulatory region of let-7a-2 is associated with an increased risk for diabetic nephropathy. Gene 2013, 527, 456-461. [CrossRef] [PubMed] 
177. Wang, T.T.; Chen, Y.J.; Sun, L.L.; Zhang, S.J.; Zhou, Z.Y.; Qiao, H. Affection of single-nucleotide polymorphisms in miR-27a, miR-124a, and miR-146a on susceptibility to type 2 diabetes mellitus in Chinese Han people. Chin. Med. J. 2015, 128, 533-539. [CrossRef] [PubMed]

178. Jensen, M.D.; Ryan, D.H.; Apovian, C.M.; Ard, J.D.; Comuzzie, A.G.; Donato, K.A.; Hu, F.B.; Hubbard, V.S.; Jakicic, J.M.; Kushner, R.F.; et al. 2013 AHA/ACC/TOS Guideline for the Management of Overweight and Obesity in Adults: A Report of the American College of Cardiology/American Heart Association Task Force on Practice Guidelines and The Obesity Society. J. Am. Coll. Cardiol. 2014, 63, 2985-3023. [CrossRef] [PubMed]

179. Shi, C.; Huang, F.; Gu, X.; Zhang, M.; Wen, J.; Wang, X.; You, L.; Cui, X.; Ji, C.; Guo, X. Adipogenic miRNA and meta-signature miRNAs involved in human adipocyte differentiation and obesity. Oncotarget 2016, 7, 40830-40845. [CrossRef] [PubMed]

180. Kim, S.Y.; Kim, A.Y.; Lee, H.W.; Son, Y.H.; Lee, G.Y.; Lee, J.W.; Lee, Y.S.; Kim, J.B. miR-27a is a negative regulator of adipocyte differentiation via suppressing PPARgamma expression. Biochem. Biophys. Res. Commun. 2010, 392, 323-328. [CrossRef] [PubMed]

181. Karbiener, M.; Fischer, C.; Nowitsch, S.; Opriessnig, P.; Papak, C.; Ailhaud, G.; Dani, C.; Amri, E.Z.; Scheideler, M. microRNA miR-27b impairs human adipocyte differentiation and targets PPARgamma. Biochem. Biophys. Res. Commun. 2009, 390, 247-251. [CrossRef] [PubMed]

182. Tyagi, S.; Gupta, P.; Saini, A.S.; Kaushal, C.; Sharma, S. The peroxisome proliferator-activated receptor: A family of nuclear receptors role in various diseases. J. Adv. Pharm. Technol. Res. 2011, 2, 236-240. [CrossRef] [PubMed]

183. Song, G.; Xu, G.; Ji, C.; Shi, C.; Shen, Y.; Chen, L.; Zhu, L.; Yang, L.; Zhao, Y.; Guo, X. The role of microRNA-26b in human adipocyte differentiation and proliferation. Gene 2014, 533, 481-487. [CrossRef] [PubMed]

184. Xu, G.; Ji, C.; Song, G.; Zhao, C.; Shi, C.; Song, L.; Chen, L.; Yang, L.; Huang, F.; Pang, L.; et al. MiR-26b modulates insulin sensitivity in adipocytes by interrupting the PTEN/PI3K/AKT pathway. Int. J. Obes. 2015, 39, 1523-1530. [CrossRef] [PubMed]

185. Skårn, M.; Namløs, H.M.; Noordhuis, P.; Wang, M.Y.; Meza-Zepeda, L.A.; Myklebost, O. Adipocyte differentiation of human bone marrow-derived stromal cells is modulated by microRNA-155, microRNA-221, and microRNA-222. Stem Cells Dev. 2012, 21, 873-883. [CrossRef] [PubMed]

186. Hamam, D.; Ali, D.; Vishnubalaji, R.; Hamam, R.; Al-Nbaheen, M.; Chen, L.; Kassem, M.; Aldahmash, A.; Alajez, N.M. microRNA-320/RUNX2 axis regulates adipocytic differentiation of human mesenchymal (skeletal) stem cells. Cell Death Dis. 2014, 5, e1499. [CrossRef] [PubMed]

187. Karbiener, M.; Pisani, D.F.; Frontini, A.; Oberreiter, L.M.; Lang, E.; Vegiopoulos, A.; Mössenböck, K.; Bernhardt, G.A.; Mayr, T.; Hildner, F.; et al. MicroRNA-26 Family Is Required for Human Adipogenesis and Drives Characteristics of Brown Adipocytes. Stem Cells 2014, 32, 1578-1590. [CrossRef] [PubMed]

188. Pal, A.; Barber, T.M.; de Bunt, M.; Rudge, S.A.; Zhang, Q.; Lachlan, K.L.; Cooper, N.S.; Linden, H.; Levy, J.C.; Wakelam, M.J.; et al. PTEN mutations as a cause of constitutive insulin sensitivity and obesity. N. Engl. J. Med. 2012, 367, 1002-1011. [CrossRef] [PubMed]

189. Jordan, S.D.; Krüger, M.; Willmes, D.M.; Redemann, N.; Wunderlich, F.T.; Brönneke, H.S.; Merkwirth, C.; Kashkar, H.; Olkkonen, V.M.; Böttger, T.; et al. Obesity-induced overexpression of miRNA-143 inhibits insulin-stimulated AKT activation and impairs glucose metabolism. Nat. Cell Biol. 2011, 13, 434-446. [CrossRef] [PubMed]

190. Trajkovski, M.; Hausser, J.; Soutschek, J.; Bhat, B.; Akin, A.; Zavolan, M.; Heim, M.H.; Stoffel, M. MicroRNAs 103 and 107 regulate insulin sensitivity. Nature 2011, 474, 649-653. [CrossRef] [PubMed]

191. Togliatto, G.; Dentelli, P.; Gili, M.; Gallo, S.; Deregibus, C.; Biglieri, E.; Iavello, A.; Santini, E.; Rossi, C.; Solini, A.; et al. Obesity reduces the pro-angiogenic potential of adipose tissue stem cell-derived extracellular vesicles (EVs) by impairing miR-126 content: Impact on clinical applications. Int. J. Obes. 2016, 40, 102-111. [CrossRef] [PubMed]

192. Jansen, F.; Yang, X.; Hoelscher, M.; Cattelan, A.; Schmitz, T.; Proebsting, S.; Wenzel, D.; Vosen, S.; Franklin, B.S.; Fleischmann, B.K.; et al. Endothelial microparticle-mediated transfer of MicroRNA-126 promotes vascular endothelial cell repair via SPRED1 and is abrogated in glucose-damaged endothelial microparticles. Circulation 2013, 128, 2026-2038. [CrossRef] [PubMed] 
193. Kim, Y.J.; Hwang, S.J.; Bae, Y.C.; Jung, J.S. MiR-21 regulates adipogenic differentiation through the modulation of TGF-beta signaling in mesenchymal stem cells derived from human adipose tissue. Stem Cells 2009, 27, 3093-3102. [CrossRef] [PubMed]

194. Seeger, T.; Fischer, A.; Muhly-Reinholz, M.; Zeiher, A.M.; Dimmeler, S. Long-term inhibition of miR-21 leads to reduction of obesity in $\mathrm{db} / \mathrm{db}$ mice. Obesity (Silver Spring) 2014, 22, 2352-2360. [CrossRef] [PubMed]

195. Qin, L.; Chen, Y.; Niu, Y.; Chen, W.; Wang, Q.; Xiao, S.; Li, A.; Xie, Y.; Li, J.; Zhao, X.; et al. A deep investigation into the adipogenesis mechanism: Profile of microRNAs regulating adipogenesis by modulating the canonical Wnt/beta-catenin signaling pathway. BMC Genomics 2010, 11, 320. [CrossRef] [PubMed]

196. Roldan, M.; Macias-Gonzalez, M.; Garcia, R.; Tinahones, F.J.; Martin, M. Obesity short-circuits stemness gene network in human adipose multipotent stem cells. FASEB J. 2011, 25, 4111-4126. [CrossRef] [PubMed]

197. Chen, L.; Dai, Y.M.; Ji, C.B.; Yang, L.; Shi, C.M.; Xu, G.F.; Pang, L.X.; Huang, F.Y.; Zhang, C.M.; Guo, X.R. $\mathrm{MiR}-146 \mathrm{~b}$ is a regulator of human visceral preadipocyte proliferation and differentiation and its expression is altered in human obesity. Mol. Cell. Endocrinol. 2014, 393, 65-74. [CrossRef] [PubMed]

198. Kawamura, Y.; Tanaka, Y.; Kawamori, R.; Maeda, S. Overexpression of Kruppel-like factor 7 regulates adipocytokine gene expressions in human adipocytes and inhibits glucose-induced insulin secretion in pancreatic $\beta$-cell line. Mol. Endocrinol. 2006, 20, 844-856. [CrossRef] [PubMed]

199. Barbagallo, D.; Condorelli, A.G.; Piro, S.; Parrinello, N.; Fløyel, T.; Ragusa, M.; Rabuazzo, A.M.; Størling, J.; Purrello, F.; Di Pietro, C.; et al. CEBPA exerts a specific and biologically important proapoptotic role in pancreatic $\beta$ cells through its downstream network targets. Mol. Biol. Cell 2014, 25, 2333-2341. [CrossRef] [PubMed]

200. Kanazawa, A.; Kawamura, Y.; Sekine, A.; Iida, A.; Tsunoda, T.; Kashiwagi, A.; Tanaka, Y.; Babazono, T.; Matsuda, M.; Kawai, K.; et al. Single nucleotide polymorphisms in the gene encoding Krüppel-like factor 7 are associated with type 2 diabetes. Diabetologia 2005, 48, 1315-1322. [CrossRef] [PubMed]

201. Martinelli, R.; Nardelli, C.; Pilone, V.; Buonomo, T.; Liguori, R.; Castanò, I.; Buono, P.; Masone, S.; Persico, G.; Forestieri, P.; et al. miR-519d Overexpression Is Associated with Human Obesity. Obesity 2010, 18, 2170-2176. [CrossRef] [PubMed]

202. Hulsmans, M.; Sinnaeve, P.; der Schueren, B.; Mathieu, C.; Janssens, S.; Holvoet, P. Decreased miR-181a expression in monocytes of obese patients is associated with the occurrence of metabolic syndrome and coronary artery disease. J. Clin. Endocrinol. Metab. 2012, 97, E1213-E1218. [CrossRef] [PubMed]

203. Deiuliis, J.A.; Syed, R.; Duggineni, D.; Rutsky, J.; Rengasamy, P.; Zhang, J.; Huang, K.; Needleman, B.; Mikami, D.; Perry, K.; et al. Visceral Adipose MicroRNA 223 Is Upregulated in Human and Murine Obesity and Modulates the Inflammatory Phenotype of Macrophages. PLoS ONE 2016, 11, e0165962. [CrossRef] [PubMed]

204. Iacomino, G.; Russo, P.; Stillitano, I.; Lauria, F.; Marena, P.; Ahrens, W.; de Luca, P.; Siani, A. Circulating microRNAs are deregulated in overweight/obese children: Preliminary results of the I.Family study. Genes Nutr. 2016, 11, 7. [CrossRef] [PubMed]

205. Wu, L.; Dai, X.; Zhan, J.; Zhang, Y.; Zhang, H.; Zhang, H.; Zeng, S.; Xi, W. Profiling peripheral microRNAs in obesity and type 2 diabetes mellitus. APMIS 2015, 123, 580-585. [CrossRef] [PubMed]

206. Ortega, F.J.; Mercader, J.M.; Catalán, V.; Moreno-Navarrete, J.M.; Pueyo, N.; Sabater, M.; Gómez-Ambrosi, J.; Anglada, R.; Fernández-Formoso, J.A.; Ricart, W.; et al. Targeting the circulating microRNA signature of obesity. Clin. Chem. 2013, 59, 781-792. [CrossRef] [PubMed]

207. Wen, D.; Qiao, P.; Wang, L. Circulating microRNA-223 as a potential biomarker for obesity. Obes. Res. Clin. Pract. 2015, 9, 398-404. [CrossRef] [PubMed]

208. Kilic, I.D.; Dodurga, Y.; Uludag, B.; Alihanoglu, Y.I.; Yildiz, B.S.; Enli, Y.; Secme, M.; Bostanc1, H.E. MicroRNA-143 and -223 in obesity. Gene 2015, 560, 140-142. [CrossRef] [PubMed]

209. Bruun, J.M.; Stallknecht, B.; Helge, J.W.; Richelsen, B. Interleukin-18 in plasma and adipose tissue: Effects of obesity, insulin resistance, and weight loss. Eur. J. Endocrinol. 2007, 157, 465-471. [CrossRef] [PubMed]

210. Davis, B.K.; Wen, H.; Ting, J.P.Y. The inflammasome NLRs in immunity, inflammation, and associated diseases. Annu. Rev. Immunol. 2011, 29, 707-735. [CrossRef] [PubMed]

211. Kaplanski, G. Interleukin-18: Biological properties and role in disease pathogenesis. Immunol. Rev. 2018, 281, 138-153. [CrossRef] [PubMed] 
212. Li, P.; Li, Y.; Li, Z.; Wu, Y.; Zhang, C.; Ai, X.; Wang, C.; Shi, H.; Hui, M.; Xie, B.; et al. Cross talk between vascular smooth muscle cells and monocytes through interleukin-1 $\beta /$ interleukin-18 signaling promotes vein graft thickening. Arterioscler. Thromb. Vasc. Biol. 2014, 34, 2001-2011. [CrossRef] [PubMed]

213. Sims, J.E. IL-1 and IL-18 receptors, and their extended family. Curr. Opin. Immunol. 2002, 14, 117-122. [CrossRef]

214. Martínez-Barquero, V.; Marco, G.; de Martínez-Hervas, S.; Adam-Felici, V.; Pérez-Soriano, C.; Gonzalez-Albert, V.; Rojo, G.; Ascaso, J.F.; Real, J.T.; Garcia-Garcia, A.B.; et al. Are IL18RAP gene polymorphisms associated with body mass regulation? A cross-sectional study. BMJ Open 2017, 7, e017875. [CrossRef] [PubMed]

215. Zaragosi, L.E.; Wdziekonski, B.; Brigand, K.L.; Villageois, P.; Mari, B.; Waldmann, R.; Dani, C.; Barbry, P. Small RNA sequencing reveals miR-642a-3p as a novel adipocyte-specific microRNA and miR-30 as a key regulator of human adipogenesis. Genome Biol. 2011, 12, R64. [CrossRef] [PubMed]

216. Meale, S.J.; Romao, J.M.; He, M.L.; Chaves, A.V.; McAllister, T.A.; Guan, L.L. Effect of diet on microRNA expression in ovine subcutaneous and visceral adipose tissues. J. Anim. Sci. 2014, 92, 3328-3337. [CrossRef] [PubMed]

217. Schneeberger, M.; Gomez-Valadés, A.G.; Ramirez, S.; Gomis, R.; Claret, M. Hypothalamic miRNAs: Emerging roles in energy balance control. Front. Neurosci. 2015, 9, 41. [CrossRef] [PubMed]

218. Richardson, K.; Lai, C.Q.; Parnell, L.D.; Lee, Y.C.; Ordovas, J.M. A genome-wide survey for SNPs altering microRNA seed sites identifies functional candidates in GWAS. BMC Genomics 2011, 12, 504. [CrossRef] [PubMed]

219. Tansey, J.T.; Sztalryd, C.; Gruia-Gray, J.; Roush, D.L.; Zee, J.V.; Gavrilova, O.; Reitman, M.L.; Deng, C.X.; Li, C.; Kimmel, A.R.; et al. Perilipin ablation results in a lean mouse with aberrant adipocyte lipolysis, enhanced leptin production, and resistance to diet-induced obesity. Proc. Natl. Acad. Sci. USA 2001, 98, 6494-6499. [CrossRef] [PubMed]

220. Alcântara, V.M.; Oliveira, L.C.; Réa, R.R.; Suplicy, H.L.; Chautard-Freire-Maia, E.A. Butyrylcholinesterase activity and metabolic syndrome in obese patients. Clin. Chem. Lab. Med. 2005, 43, 285-288. [CrossRef] [PubMed]

221. Sisková, K.; Bilka, F.; Adameová, A.; Balazová, A.; Mydla, M.; Pauliková, I. Influence of lipid imbalance on butyrylcholinesterase activity and biotransformation efficiency. Pharmazie 2012, 67, 345-350. [PubMed]

222. Lima, J.K.; Leite, N.; Turek, L.V.; Souza, R.L.R.; da Silva Timossi, L.; Osiecki, A.C.V.; Osiecki, R.; Furtado-Alle, L. 1914G variant of BCHE gene associated with enzyme activity, obesity and triglyceride levels. Gene 2013, 532, 24-26. [CrossRef] [PubMed]

223. Duygu, B.; Da Costa Martins, P.A. miR-21: A star player in cardiac hypertrophy. Cardiovasc. Res. 2015, 105, 235-237. [CrossRef] [PubMed]

224. Sell, H.; Dietze-Schroeder, D.; Kaiser, U.; Eckel, J. Monocyte chemotactic protein-1 is a potential player in the negative cross-talk between adipose tissue and skeletal muscle. Endocrinology 2006, 147, 2458-2467. [CrossRef] [PubMed]

225. Ding, S.; Huang, H.; Xu, Y.; Zhu, H.; Zhong, C. MiR-222 in cardiovascular diseases: Physiology and pathology. BioMed Res. Int. 2017, 2017, 4962426. [CrossRef] [PubMed]

226. Li, B.; Fan, J.; Chen, N. A novel regulator of type II diabetes: MicroRNA-143. Trends Endocrinol. Metab. 2018, 29, 380-388. [CrossRef] [PubMed]

227. Ono, K. MicroRNA links obesity and impaired glucose metabolism. Cell Res. 2011, 21, 864-866. [CrossRef] [PubMed]

228. Karolina, D.S.; Tavintharan, S.; Armugam, A.; Sepramaniam, S.; Pek, S.L.T.; Wong, M.T.K.; Lim, S.C.; Sum, C.F.; Jeyaseelan, K. Circulating miRNA Profiles in Patients with Metabolic Syndrome. J. Clin. Endocrinol. Metab. 2012, 97, E2271-E2276. [CrossRef] [PubMed]

229. Oja, P.; Titze, S. Physical activity recommendations for public health: Development and policy context. EPMA J. 2011, 2, 253-259. [CrossRef] [PubMed]

230. Zhang, H.; Jiang, L.; Yang, Y.J.; Ge, R.K.; Zhou, M.; Hu, H.; Liu, H.; Cui, J.; Li, L.L.; Dong, Y.F.; et al. Aerobic exercise improves endothelial function and serum adropin levels in obese adolescents independent of body weight loss. Sci. Rep. 2017, 7, 17717. [CrossRef] [PubMed]

231. Clauss, S.; Wakili, R.; Hildebrand, B.; Kääb, S.; Hoster, E.; Klier, I.; Martens, E.; Hanley, A.; Hanssen, H.; Halle, M.; et al. MicroRNAs as biomarkers for acute atrial remodeling in marathon runners (the mirathon study-A sub-study of the munich marathon study). PLoS ONE 2016, 11, e0148599. [CrossRef] [PubMed] 
232. Börjesson, M.; Onerup, A.; Lundqvist, S.; Dahlöf, B. Physical activity and exercise lower blood pressure in individuals with hypertension: Narrative review of 27 RCTs. Br. J. Sports Med. 2016, 50, 356-361. [CrossRef] [PubMed]

233. Zhao, R.R.; O'Sullivan, A.J.; Fiatarone Singh, M.A. Exercise or physical activity and cognitive function in adults with type 2 diabetes, insulin resistance or impaired glucose tolerance: A systematic review. Eur. Rev. Aging Phys. Act. 2018, 15, 1. [CrossRef] [PubMed]

234. Ingul, C.B.; Dias, K.A.; Tjonna, A.E.; Follestad, T.; Hosseini, M.S.; Timilsina, A.S.; Hollekim-Strand, S.M.; Ro, T.B.; Davies, P.S.W.; Cain, P.A.; et al. Effect of High Intensity Interval Training on Cardiac Function in Children with Obesity: A Randomised Controlled Trial. Prog. Cardiovasc. Dis. 2018. [CrossRef] [PubMed]

235. Fonseca-Junior, S.J.; Sá, C.G.A.d.B.; Rodrigues, P.A.F.; Oliveira, A.J.; Fernandes-Filho, J. Physical exercise and morbid obesity: A systematic review. Arq. Bras. Cir. Dig. 2013, 26, 67-73. [CrossRef] [PubMed]

236. Ferioli, M.; Zauli, G.; Martelli, A.M.; Vitale, M.; McCubrey, J.A.; Ultimo, S.; Capitani, S.; Neri, L.M. Impact of physical exercise in cancer survivors during and after antineoplastic treatments. Oncotarget 2018, 9, 14005-14034. [CrossRef] [PubMed]

237. Wang, L.; Ai, D.; Zhang, N. Exercise benefits coronary heart disease. Adv. Exp. Med. Biol. 2017, 1000, 3-7. [CrossRef] [PubMed]

238. do Prado, D.M.L.; Rocco, E.A. The benefits of exercise training on aerobic capacity in patients with heart failure and preserved ejection fraction. Adv. Exp. Med. Biol. 2017, 1000, 51-64. [CrossRef] [PubMed]

239. Fernandes, T.; Soci, U.P.; Oliveira, E.M. Eccentric and concentric cardiac hypertrophy induced by exercise training: MicroRNAs and molecular determinants. Braz. J. Med. Biol. Res. 2011, 44, 836-847. [CrossRef] [PubMed]

240. Konhilas, J.P.; Watson, P.A.; Maass, A.; Boucek, D.M.; Horn, T.; Stauffer, B.L.; Luckey, S.W.; Rosenberg, P.; Leinwand, L.A. Exercise can prevent and reverse the severity of hypertrophic cardiomyopathy. Circ. Res. 2006, 98, 540-548. [CrossRef] [PubMed]

241. Novoa, U.; Arauna, D.; Moran, M.; Nuñez, M.; Zagmutt, S.; Saldivia, S.; Valdes, C.; Villaseñor, J.; Zambrano, C.G.; Gonzalez, D.R. High-intensity exercise reduces cardiac fibrosis and hypertrophy but does not restore the nitroso-redox imbalance in diabetic cardiomyopathy. Oxid. Med. Cell. Longev. 2017, 2017, 7921363. [CrossRef] [PubMed]

242. Giannuzzi, P.; Temporelli, P.L.; Corrà, U.; Tavazzi, L.; ELVD-CHF Study Group. Antiremodeling effect of long-term exercise training in patients with stable chronic heart failure: Results of the exercise in left ventricular dysfunction and chronic heart failure (ELVD-CHF) trial. Circulation 2003, 108, 554-559. [CrossRef] [PubMed]

243. Xu, X.; Wan, W.; Powers, A.S.; Li, J.; Ji, L.L.; Lao, S.; Wilson, B.; Erikson, J.M.; Zhang, J.Q. Effects of exercise training on cardiac function and myocardial remodeling in post myocardial infarction rats. J. Mol. Cell. Cardiol. 2008, 44, 114-122. [CrossRef] [PubMed]

244. Nielsen, S.; Åkerström, T.; Rinnov, A.; Yfanti, C.; Scheele, C.; Pedersen, B.K.; Laye, M.J. The miRNA plasma signature in response to acute aerobic exercise and endurance training. PLoS ONE 2014, 9, e87308. [CrossRef] [PubMed]

245. Silva, G.J.J.; Bye, A.; el Azzouzi, H.; Wisløff, U. MicroRNAs as important regulators of exercise adaptation. Prog. Cardiovasc. Dis. 2017, 60, 130-151. [CrossRef] [PubMed]

246. Ma, Z.; Qi, J.; Meng, S.; Wen, B.; Zhang, J. Swimming exercise training-induced left ventricular hypertrophy involves microRNAs and synergistic regulation of the PI3K/AKT/mTOR signaling pathway. Eur. J. Appl. Physiol. 2013, 113, 2473-2486. [CrossRef] [PubMed]

247. Zhao, Y.; Ma, Z. Swimming training affects apoptosis-related microRNAs and reduces cardiac apoptosis in mice. Gene Physiol. Biophys. 2016, 35, 443-450. [CrossRef] [PubMed]

248. Dias, R.G.; Silva, M.S.M.; Duarte, N.E.; Bolani, W.; Alves, C.R.; Junior, J.R.L.; da Silva, J.L.; de Oliveira, P.A.; Alves, G.B.; de Oliveira, E.M.; et al. PBMCs express a transcriptome signature predictor of oxygen uptake responsiveness to endurance exercise training in men. Physiol. Genomics 2015, 47, 13-23. [CrossRef] [PubMed]

249. Radom-Aizik, S.; Zaldivar, F.; Leu, S.Y.; Adams, G.R.; Oliver, S.; Cooper, D.M. Effects of exercise on microRNA expression in young males peripheral blood mononuclear cells. Clin. Transl. Sci. 2012, 5, 32-38. [CrossRef] [PubMed] 
250. Baggish, A.L.; Hale, A.; Weiner, R.B.; Lewis, G.D.; Systrom, D.; Wang, F.; Wang, T.J.; Chan, S.Y. Dynamic regulation of circulating microRNA during acute exhaustive exercise and sustained aerobic exercise training. J. Physiol. 2011, 589, 3983-3994. [CrossRef] [PubMed]

251. Baggish, A.L.; Park, J.; Min, P.K.; Isaacs, S.; Parker, B.A.; Thompson, P.D.; Troyanos, C.; D’Hemecourt, P.; Dyer, S.; Thiel, M.; et al. Rapid upregulation and clearance of distinct circulating microRNAs after prolonged aerobic exercise. J. Appl. Physiol. 2014, 116, 522-531. [CrossRef] [PubMed]

252. Xu, T.; Zhou, Q.; Che, L.; Das, S.; Wang, L.; Jiang, J.; Li, G.; Xu, J.; Yao, J.; Wang, H.; et al. Circulating miR-21, miR-378, and miR-940 increase in response to an acute exhaustive exercise in chronic heart failure patients. Oncotarget 2016, 7, 12414-12425. [CrossRef] [PubMed]

253. Souza, R.W.; Fernandez, G.J.; Cunha, J.P.; Piedade, W.P.; Soares, L.C.; Souza, P.A.; de Campos, D.H.; Okoshi, K.; Cicogna, A.C.; Dal-Pai-Silva, M.; et al. Regulation of cardiac microRNAs induced by aerobic exercise training during heart failure. Am. J. Physiol. Heart Circ. Physiol. 2015, 309, H1629-H1641. [CrossRef] [PubMed]

254. Yu, Y.; Du, H.; Wei, S.; Feng, L.; Li, J.; Yao, F.; Zhang, M.; Hatch, G.M.; Chen, L. Adipocyte-derived exosomal MiR-27a induces insulin resistance in skeletal muscle through repression of PPAR $\gamma$. Theranostics 2018, 8 , 2171-2188. [CrossRef] [PubMed]

255. Wang, B.; Zhang, C.; Zhang, A.; Cai, H.; Price, S.R.; Wang, X.H. MicroRNA-23a and microRNA-27a mimic exercise by ameliorating CKD-induced muscle atrophy. J. Am. Soc. Nephrol. 2017, 28, 2631-2640. [CrossRef] [PubMed]

256. Fernandes, T.; Hashimoto, N.Y.; Magalhães, F.C.; Fernandes, F.B.; Casarini, D.E.; Carmona, A.K.; Krieger, J.E.; Phillips, M.I.; Oliveira, E.M. Aerobic exercise training-induced left ventricular hypertrophy involves regulatory MicroRNAs, decreased angiotensin-converting enzyme-angiotensin ii, and synergistic regulation of angiotensin-converting enzyme 2-angiotensin (1-7). Hypertension 2011, 58, 182-189. [CrossRef] [PubMed]

257. da Silva, N.D.; Fernandes, T.; Soci, U.P.R.; Monteiro, A.W.A.; Phillips, M.I.; de Oliveira, E.M. Swimming training in rats increases cardiac MicroRNA-126 expression and angiogenesis. Med. Sci. Sports Exerc. 2012, 44, 1453-1462. [CrossRef] [PubMed]

258. Gomes, J.L.; Fernandes, T.; Soci, U.P.; Silveira, A.C.; Barretti, D.L.; Negrão, C.E.; Oliveira, E.M. Obesity downregulates microRNA-126 inducing capillary rarefaction in skeletal muscle: Effects of aerobic exercise training. Oxid. Med. Cell. Longev. 2017, 2017, 2415246. [CrossRef] [PubMed]

259. Radom-Aizik, S.; Zaldivar, F.; Haddad, F.; Cooper, D.M. Impact of brief exercise on peripheral blood NK cell gene and microRNA expression in young adults. J. Appl. Physiol. 2013, 114, 628-636. [CrossRef] [PubMed]

260. Uhlemann, M.; Möbius-Winkler, S.; Fikenzer, S.; Adam, J.; Redlich, M.; Möhlenkamp, S.; Hilberg, T.; Schuler, G.C.; Adams, V. Circulating microRNA-126 increases after different forms of endurance exercise in healthy adults. Eur. J. Prev. Cardiol. 2014, 21, 484-491. [CrossRef] [PubMed]

261. Martinelli, N.C.; Cohen, C.R.; Santos, K.G.; Castro, M.A.; Biolo, A.; Frick, L.; Silvello, D.; Lopes, A.; Schneider, S.; Andrades, M.E.; et al. An analysis of the global expression of microRNAs in an experimental model of physiological left ventricular hypertrophy. PLoS ONE 2014, 9, e93271. [CrossRef] [PubMed]

262. de Gonzalo-Calvo, D.; Dávalos, A.; Montero, A.; García-González, Á.; Tyshkovska, I.; González-Medina, A.; Soares, S.M.A.; Martínez-Camblor, P.; Casas-Agustench, P.; Rabadán, M.; et al. Circulating inflammatory miRNA signature in response to different doses of aerobic exercise. J. Appl. Physiol. 2015, 119, 124-134. [CrossRef] [PubMed]

263. Keidar, S.; Kaplan, M.; Gamliel-Lazarovich, A. ACE2 of the heart: From angiotensin I to angiotensin (1-7). Cardiovasc. Res. 2007, 73, 463-469. [CrossRef] [PubMed]

264. Gu, Q.; Wang, B.; Zhang, X.F.; Ma, Y.P.; Liu, J.D.; Wang, X.Z. Contribution of renin-angiotensin system to exercise-induced attenuation of aortic remodeling and improvement of endothelial function in spontaneously hypertensive rats. Cardiovasc. Pathol. 2014, 23, 298-305. [CrossRef] [PubMed]

265. Sheedy, F.J. Turning 21: Induction of miR-21 as a Key Switch in the Inflammatory Response. Front. Immunol. 2015, 6, 19. [CrossRef] [PubMed]

266. Fernandes, T.; Nakamuta, J.S.; Magalhães, F.C.; Roque, F.R.; Lavini-Ramos, C.; Schettert, I.T.; Coelho, V.; Krieger, J.E.; Oliveira, E.M. Exercise training restores the endothelial progenitor cells number and function in hypertension: Implications for angiogenesis. J. Hypertens. 2012, 30, 2133-2143. [CrossRef] [PubMed]

267. Wang, L.; Lee, A.; Wigg, J.; Peshavariya, H.; Liu, P.; Zhang, H. miR-126 regulation of angiogenesis in age-related macular degeneration in CNV mouse model. Int. J. Mol. Sci. 2016, 17, 895. [CrossRef] [PubMed] 
268. Tang, S.; Wang, F.; Shao, M.; Wang, Y.; Zhu, H. MicroRNA-126 suppresses inflammation in endothelial cells under hyperglycemic condition by targeting HMGB1. Vasc. Pharmacol. 2017, 88, 48-55. [CrossRef] [PubMed]

269. Liu, X.; Xiao, J.; Zhu, H.; Wei, X.; Platt, C.; Damilano, F.; Xiao, C.; Bezzerides, V.; Boström, P.; Che, L.; et al. miR-222 is necessary for exercise-induced cardiac growth and protects against pathological cardiac remodeling. Cell Metab. 2015, 21, 584-595. [CrossRef] [PubMed]

270. Yang, L.; Li, Y.; Wang, X.; Mu, X.; Qin, D.; Huang, W.; Alshahrani, S.; Nieman, M.; Peng, J.; Essandoh, K.; et al. Overexpression of miR-223 Tips the Balance of Pro- and Anti-hypertrophic Signaling Cascades toward Physiologic Cardiac Hypertrophy. J. Biol. Chem. 2016, 291, 15700-15713. [CrossRef] [PubMed]

271. Wu, X.D.; Zeng, K.; Liu, W.L.; Gao, Y.G.; Gong, C.S.; Zhang, C.X.; Chen, Y.Q. Effect of aerobic exercise on miRNA-TLR4 signaling in atherosclerosis. Int. J. Sports Med. 2014, 35, 344-350. [CrossRef] [PubMed]

272. Fernandes, T.; Magalhães, F.C.; Roque, F.R.; Phillips, M.I.; Oliveira, E.M. Exercise training prevents the microvascular rarefaction in hypertension balancing angiogenic and apoptotic factors: Role of microRNAs-16, -21, and -126. Hypertension 2012, 59, 513-520. [CrossRef] [PubMed]

273. Ramasamy, S.; Velmurugan, G.; Shanmugha Rajan, K.; Ramprasath, T.; Kalpana, K. MiRNAs with apoptosis regulating potential are differentially expressed in chronic exercise-induced physiologically hypertrophied hearts. PLoS ONE 2015, 10, e0121401. [CrossRef] [PubMed]

274. Margolis, L.M.; Rivas, D.A.; Berrone, M.; Ezzyat, Y.; Young, A.J.; McClung, J.P.; Fielding, R.A.; Pasiakos, S.M. Prolonged calorie restriction downregulates skeletal muscle mtorc1 signaling independent of dietary protein intake and associated microRNA expression. Front. Physiol. 2016, 7, 445. [CrossRef] [PubMed]

275. Radom-Aizik, S.; Zaldivar, F.P.; Haddad, F.; Cooper, D.M. Impact of brief exercise on circulating monocyte gene and microRNA expression: Implications for atherosclerotic vascular disease. Brain Behav. Immun. 2014, 39, 121-129. [CrossRef] [PubMed]

276. Wang, K.; Zhang, D.L.; Long, B.; An, T.; Zhang, J.; Zhou, L.Y.; Liu, C.Y.; Li, P.F. NFAT4-dependent miR-324-5p regulates mitochondrial morphology and cardiomyocyte cell death by targeting Mtfr1. Cell Death Dis. 2015, 6, e2007. [CrossRef] [PubMed]

277. Wang, J.; Liew, O.W.; Richards, A.M.; Chen, Y.T. Overview of microRNAs in cardiac hypertrophy, fibrosis, and apoptosis. Int. J. Mol. Sci. 2016, 17, 749. [CrossRef] [PubMed]

278. Gomes, C.P.C.; Oliveira-Jr, G.P.; Madrid, B.; Almeida, J.A.; Franco, O.L.; Pereira, R.W. Circulating miR-1, miR-133a, and miR-206 levels are increased after a half-marathon run. Biomarkers 2014, 19, 585-589. [CrossRef] [PubMed]

279. Min, P.K.; Park, J.; Isaacs, S.; Taylor, B.A.; Thompson, P.D.; Troyanos, C.; D’Hemecourt, P.; Dyer, S.; Chan, S.Y.; Baggish, A.L. Influence of statins on distinct circulating microRNAs during prolonged aerobic exercise. J. Appl. Physiol. 2016, 120, 711-720. [CrossRef] [PubMed]

280. Chen, S.; Puthanveetil, P.; Feng, B.; Matkovich, S.J.; Dorn, G.W.; Chakrabarti, S. Cardiac miR-133a overexpression prevents early cardiac fibrosis in diabetes. J. Cell. Mol. Med. 2014, 18, 415-421. [CrossRef] [PubMed]

281. Moura, J.; Børsheim, E.; Carvalho, E. The role of microRNAs in diabetic complications-special emphasis on wound healing. Genes 2014, 5, 926-956. [CrossRef] [PubMed]

282. Chen, H.; Lan, H.Y.; Roukos, D.H.; Cho, W.C. Application of microRNAs in diabetes mellitus. J. Endocrinol. 2014, 222, R1-R10. [CrossRef] [PubMed]

283. Alipoor, B.; Ghaedi, H.; Meshkani, R.; Torkamandi, S.; Saffari, S.; Iranpour, M.; Omrani, M.D. Association of miR-146a expression and type 2 diabetes mellitus: A meta-analysis. Int. J. Mol. Cell. Med. 2017, 6, 156-163. [CrossRef] [PubMed]

284. Sawada, S.; Kon, M.; Wada, S.; Ushida, T.; Suzuki, K.; Akimoto, T. Profiling of circulating microRNAs after a bout of acute resistance exercise in humans. PLOS ONE 2013, 8, e70823. [CrossRef] [PubMed]

285. Ma, X.; Becker Buscaglia, L.E.; Barker, J.R.; Li, Y. MicroRNAs in NF-kB signaling. J. Mol. Cell. Biol. 2011, 3, 159-166. [CrossRef] [PubMed]

286. Tahamtan, A.; Teymoori-Rad, M.; Nakstad, B.; Salimi, V. Anti-Inflammatory microRNAs and their potential for inflammatory diseases treatment. Front. Immunol. 2018, 9, 1377. [CrossRef] [PubMed]

287. Russell, A.P.; Lamon, S.; Boon, H.; Wada, S.; Güller, I.; Brown, E.L.; Chibalin, A.V.; Zierath, J.R.; Snow, R.J.; Stepto, N.; et al. Regulation of miRNAs in human skeletal muscle following acute endurance exercise and short-term endurance training. J. Physiol. 2013, 591, 4637-4653. [CrossRef] [PubMed] 
288. Davidsen, P.K.; Gallagher, I.J.; Hartman, J.W.; Tarnopolsky, M.A.; Dela, F.; Helge, J.W.; Timmons, J.A.; Phillips, S.M. High responders to resistance exercise training demonstrate differential regulation of skeletal muscle microRNA expression. J. Appl. Physiol. 2011, 110, 309-317. [CrossRef] [PubMed]

289. Tang, R.; Ma, F.; Li, W.; Ouyang, S.; Liu, Z.; Wu, J. miR-206-3p inhibits 3T3-L1 cell adipogenesis via the c-Met/PI3K/Akt pathway. Int. J. Mol. Sci. 2017, 18, 1510. [CrossRef] [PubMed]

290. Mooren, F.C.; Viereck, J.; Krüger, K.; Thum, T. Circulating microRNAs as potential biomarkers of aerobic exercise capacity. Am. J. Physiol. Heart Circ. Physiol. 2014, 306, H557-H563. [CrossRef] [PubMed] 